\title{
Solubility modeling of air in aqueous electrolyte solutions with the E-CPA equation of state
}

Sun, Li; Liang, Xiaodong; von Solms, Nicolas; Kontogeorgis, Georgios M.

Published in:

Industrial \& Engineering Chemistry Research

Link to article, DOI:

10.1021/acs.iecr.0c03164

Publication date:

2020

Document Version

Peer reviewed version

Link back to DTU Orbit

Citation (APA):

Sun, L., Liang, X., von Solms, N., \& Kontogeorgis, G. M. (2020). Solubility modeling of air in aqueous electrolyte solutions with the E-CPA equation of state. Industrial \& Engineering Chemistry Research, 59(41), 18693-18704. https://doi.org/10.1021/acs.iecr.0c03164

\section{General rights}

Copyright and moral rights for the publications made accessible in the public portal are retained by the authors and/or other copyright owners and it is a condition of accessing publications that users recognise and abide by the legal requirements associated with these rights.

- Users may download and print one copy of any publication from the public portal for the purpose of private study or research.

- You may not further distribute the material or use it for any profit-making activity or commercial gain

- You may freely distribute the URL identifying the publication in the public portal 


\section{I\&EC

Thermodynamics, Transport, and Fluid Mechanics

\section{Solubility Modeling of Air in Aqueous Electrolyte Solutions with the e-CPA Equation of State}

Li Sun, Xiaodong Liang, Nicolas von Solms, and Georgios M. Kontogeorgis

Ind. Eng. Chem. Res., Just Accepted Manuscript • DOI: 10.1021/acs.iecr.0c03164 • Publication Date (Web): 17 Sep 2020

Downloaded from pubs.acs.org on September 28, 2020

\section{Just Accepted}

"Just Accepted" manuscripts have been peer-reviewed and accepted for publication. They are posted online prior to technical editing, formatting for publication and author proofing. The American Chemical Society provides "Just Accepted" as a service to the research community to expedite the dissemination of scientific material as soon as possible after acceptance. "Just Accepted" manuscripts appear in full in PDF format accompanied by an HTML abstract. "Just Accepted" manuscripts have been fully peer reviewed, but should not be considered the official version of record. They are citable by the Digital Object Identifier (DOI®). "Just Accepted" is an optional service offered to authors. Therefore, the "Just Accepted" Web site may not include all articles that will be published in the journal. After a manuscript is technically edited and formatted, it will be removed from the "Just Accepted" Web site and published as an ASAP article. Note that technical editing may introduce minor changes to the manuscript text and/or graphics which could affect content, and all legal disclaimers and ethical guidelines that apply to the journal pertain. ACS cannot be held responsible for errors or consequences arising from the use of information contained in these "Just Accepted" manuscripts. 
Solubility Modeling of Air in Aqueous Electrolyte Solutions with the e-CPA Equation of State

Li Sun, Xiaodong Liang*, Nicolas von Solms, Georgios M. Kontogeorgis*

Center for Energy Resources Engineering

Department of Chemical and Biochemical Engineering

Technical University of Denmark

Søltofts Plads, Building 229

2800 Kgs. Lyngby, Denmark

Keywords: e-CPA; Air; Gas Solubility; Salting-out Effects 


\begin{abstract}
Accurate prediction of the solubilities of air (as well as nitrogen: $\mathrm{N}_{2}$, oxygen: $\mathrm{O}_{2}$ and argon) in aqueous electrolyte solutions is very important for geological studies and in the chemical industry. However, very few electrolyte equations of state have been successfully used for the calculations of these gas solubilities. This work presents a thermodynamic modeling study on the solubilities of $\mathrm{N}_{2}, \mathrm{O}_{2}$, argon and gas mixtures in pure water and aqueous solutions of several inorganic salts with the electrolyte Cubic Plus Association equation of state (e-CPA). The binary interaction parameters between cation/anion and gas are obtained by fitting the experimental data of gas solubilities in single-salt solutions. The results show that e-CPA can satisfactorily correlate the gas solubilities for most systems. For example, e-CPA gives deviations of $4 \%$ for the $\mathrm{O}_{2}$ solubilities in aqueous $\mathrm{NaCl}$ solution. e-CPA is then applied to predict the solubilities of gas mixtures and multi-salt systems (gas mixture in pure water and gas mixture in aqueous multi-salt solutions), and satisfactory performance is achieved. For example, e-CPA gives deviations of $4 \%$ for the air solubilities in aqueous $\mathrm{NaCl}$ solution.
\end{abstract}




\section{Introduction}

Nitrogen $\left(\mathrm{N}_{2}\right)$ and oxygen $\left(\mathrm{O}_{2}\right)$ are the two most abundant gases in Earth's atmosphere, and they are also significant for the whole Earth's eco-system ${ }^{1}$. Argon is also a main component of air. The natural fluids usually contain ions (e.g. $\mathrm{Na}^{+}, \mathrm{K}^{+}, \mathrm{Mg}^{2+}, \mathrm{Ca}^{2+}, \mathrm{Cl}^{-}$, $\mathrm{SO}_{4}^{2-}$ et al. $)^{2}$, whereas gas dissolution in the electrolyte solutions also occurs in many industrial processes ${ }^{3}$. Therefore, the investigation of air (as well as $\mathrm{N}_{2}, \mathrm{O}_{2}$ and argon) solubilities in electrolyte solutions is a very important part for geochemistry studies ${ }^{4}$, chemical industry ${ }^{5}$ and biology studies (e.g. gas solubility in tissues and some biological systems $)^{6}$.

Some experimental works of gas $\left(\mathrm{N}_{2}, \mathrm{O}_{2}\right.$, argon and air) solubilities in aqueous electrolyte solutions have been reported ${ }^{7-9}$, but unfortunately, these experimental data are scattered and the pressure-temperature-molality (salt) ranges are limited.

Via the so-called $\varphi-\varphi$ approach, an electrolyte equation of state (e-EoS) provides a consistent thermodynamic framework to model the gas solubilities, to extrapolate the predictions beyond the range of experimental conditions, as well as to calculate other properties (e.g. density and thermal properties). Some modeling works using e-EoS have been presented for gas (e.g. carbon dioxide: $\mathrm{CO}_{2}$, methane: $\mathrm{CH}_{4}$ ) solubility calculations $^{10-21}$.

Here, we give a short review on several aspects of these e-EoS modeling works. The first aspect is related to relative static permittivity, which is a very important physical quantity for electrostatic calculations. Zuo and Guo ${ }^{12}$, Sun and Dubessy ${ }^{14}$, Tan et al. ${ }^{17}$, and Ji et. al. ${ }^{15}$ assumed that the relative static permittivity of electrolyte solution is equal to that of the solvent. Other models ${ }^{10-11,13,16,18-20}$ take the effect of salt presence on relative static permittivity into account. The other important aspect is the Born term. Søreide and Whitson ${ }^{13}$, Aasberg-Petersen et al. ${ }^{11}$, Haghighi et al. ${ }^{16}$, and Sun and Dubessy $^{14,22}$ did not explicitly take the ion solvation contribution into account, while other models included the ion solvation contribution via the Born term, which is believed to be important for salting-out effects and the thermodynamic modeling of other properties and behaviours. 
Very few e-EoS have been presented to predict gas solubilities of $\mathrm{N}_{2}{ }^{13}, \mathrm{O}_{2}$, argon and air so far. Soreide and Whitson's model ${ }^{13}$ cannot predict $\mathrm{N}_{2}$ solubilities in aqueous $\mathrm{NaCl}$ solution well above 300 bar, and the temperature range is narrow in their studies. To the best of our knowledge, extensive modeling works for gas mixture and multi-salt systems have not been reported with electrolyte equations of state.

The electrolyte Cubic Plus Association equation of state (e-CPA) is an extension of Cubic Plus Association equation of state (CPA), which is suitable for describing associating fluids. The e-CPA includes an ion-ion interaction term and an ion-water interaction term, and considers the effect of salt presence on relative static permittivity. e-CPA has been successfully applied in modeling the dissolution of some gases in aqueous electrolyte solutions ${ }^{23}$. e-CPA is selected as the thermodynamic model in this work.

This work investigates a thermodynamic modeling of gas solubilities of $\mathrm{N}_{2}, \mathrm{O}_{2}$, argon and gas mixtures in pure water and aqueous electrolyte solutions. This manuscript is organized as follows: a short introduction of the thermodynamic model is first presented, followed by the parameter estimation. Then, both the correlative and predictive results are presented and discussed, followed by the conclusions. Supplementary information is available in the Supporting Information.

\section{The Thermodynamic Model}

\subsection{The e-CPA EoS}

e-CPA was developed by Maribo-Mogensen et al. ${ }^{24}$, and it is an extension of CPA proposed by Kontogeorgis et al. ${ }^{25}$

In terms of residual Helmholtz energy, e-CPA can be written:

$$
A^{R e s}=A^{S R K}+A^{A s s o c}+A^{D H}+A^{\text {Born }}
$$

Where $A^{S R K}$ and $A^{A S S o c}$ are the two contributions from the cubic equation of state (Soave-Redlich-Kwong ${ }^{26}$ ) and the association term, $A^{D H}$ is from the Debye-Hückel (DH) theory ${ }^{27}$ and $A^{\text {Born }}$ is from the Born equation ${ }^{28}$.

The classical van der Waals one-fluid mixing rule is used for the energy parameter for 
two non-ionic molecules, while the Huron-Vidal/NRTL mixing rule is used when an ion is involved ${ }^{24}$. The HV-NRTL infinite pressure mixing rule reduces to the one-fluid mixing rule if the non-randomness parameter $\left(\alpha_{j i}\right)$ is set to zero and the binary interaction parameter between cation/anion and molecules $\left(\Delta U_{i j}^{r e f}\right)$ is appropriately chosen, for which more details can be found in the book from Michelsen and Mollerup ${ }^{29}$. More details about the e-CPA EoS can be found in Section A of Supporting Information and the original paper ${ }^{24}$.

\subsection{Parameter Estimation}

From Section A of Supporting Information and the original e-CPA paper ${ }^{24}$, it can be seen that the binary interaction parameters of ions with water or gas are: NRTL nonrandomness parameter $\left(\alpha_{j i}\right)$, interaction parameter at the reference temperature $\left(\Delta U_{i j}^{r e f}\right)$, and the two adjustable parameters of the temperature dependency $\left(\omega_{\Delta U_{i j}}\right.$ and $\left.T_{\Delta U_{i j}}\right)$. In this work, the NRTL non-randomness factor and the ion-ion interaction parameters are set to zero. Moreover, the ion-solvent and ion-gas interaction parameters are transformed to cation/anion-solvent, and cation/anion-gas interaction parameters, which means that interaction parameters $\Delta U_{\text {cation-solvent }}$ is equal to $\Delta U_{\text {anion-solvent }}$, and $\Delta U_{\text {cation-gas }}$ is equal to $\Delta U_{\text {anion-gas }}$.

The cation/anion-solvent interaction parameters are obtained by fitting mean ionic activity coefficients and osmotic coefficients. These parameters have been presented by Maribo-Mogensen et al. ${ }^{24}$ We have further validated these parameters for several $\mathrm{H}_{2} \mathrm{O}+$ salt binary systems. The interaction parameters and the verification results can be found in Table S1 of Supporting Information.

The cation/anion-gas interaction parameters are obtained by fitting gas solubilities in aqueous single-salt solutions. In the optimizations, if the experimental data are lacking, the temperature-dependency of interaction parameters (i.e. $\omega_{\Delta U_{i j}}$ and $T_{\Delta U_{i j}}$ ) is not considered, i.e. only one interaction parameter (interaction parameter at the reference temperature, $\Delta U_{i j}^{r e f}$ ) is used. 
The gas solubilities in an electrolyte solution is calculated by a two-phase PT-flash with the successive substitution method ${ }^{29-30}$. The MATLAB built-in function "fmincon" is used for the regression, for which the objective function is:

$$
F=\sum_{i}^{N p}\left[\frac{x_{i}^{c a l}-x_{i}^{e x p}}{x_{i}^{e x p}}\right]^{2}
$$

Where $N p$ is the number of data points, $x_{i}^{c a l}$ represents the calculated values (gas solubilities), and $x_{i}^{\text {exp }}$ represents the corresponding experimental values.

The results are typically presented as the relative average deviation (RAD):

$$
R A D \%=\frac{1}{N p} \sum_{i}^{N p}\left|\frac{y_{i}^{c a l}-y_{i}^{e x p}}{y_{i}^{e x p}}\right| \times 100 \%
$$

Here, $y_{i}^{c a l}$ represents the calculated results of a given property (mean ionic activity coefficient, osmotic coefficient or gas solubility), and $y_{i}^{\text {exp }}$ represents the corresponding experimental data.

In this work, the $\mathrm{H}_{2} \mathrm{O}$-gas interaction parameters are obtained from $\mathrm{H}_{2} \mathrm{O}+$ single-gas systems, while the cation/anion-gas interaction parameters are obtained from the ternary $\mathrm{H}_{2} \mathrm{O}+$ single-gas + single-salt systems. Thus, the calculations of the solubilities of single-gas in pure water and aqueous single-salt solution should be considered correlations. On the other hand, there are no additional adjustable parameters in modeling for the $\mathrm{H}_{2} \mathrm{O}+$ gas mixture, $\mathrm{H}_{2} \mathrm{O}+$ gas mixture+single-salt and $\mathrm{H}_{2} \mathrm{O}+$ gas mixture + multi-salt systems, so, the calculations of these systems are predictions.

\section{Gas Solubilities in Pure Water}

\subsection{Correlations of Solubilities of Single-Gas}

Prior to modeling the gas solubilities in aqueous electrolyte solutions, the gas solubilities in pure water are considered. For such systems, e-CPA reduces to CPA due to the absence of electrolytes.

The modeling of single-gas solubilities in pure water is a correlation task. The $\mathrm{H}_{2} \mathrm{O}$-gas interaction parameters are obtained by fitting gas solubilities in pure water. In our previous works, the interaction parameters of $\mathrm{H}_{2} \mathrm{O}-\mathrm{N}_{2}{ }^{31}, \mathrm{H}_{2} \mathrm{O}-\mathrm{CO}_{2}{ }^{23}$, and $\mathrm{H}_{2} \mathrm{O}-\mathrm{CH}_{4}{ }^{23}$ 
were obtained. The interaction parameters of $\mathrm{H}_{2} \mathrm{O}-\mathrm{O}_{2}$ and $\mathrm{H}_{2} \mathrm{O}$-argon are obtained in this work. The $\mathrm{H}_{2} \mathrm{O}$-gas interaction parameters and modeling results are presented in Table 1 and Figures S1-S2 of Supporting Information. The corresponding CPA pure component parameters can be found in Table S2 of Supporting Information, in which the parameters of argon are obtained in this work by fitting the saturation pressure and liquid density. Table S3 of Supporting Information lists the $\mathrm{H}_{2} \mathrm{O}$-gas interaction parameters and modelling performance of gas solubilities in pure water, from which it can be seen that CPA correlates well the gas solubilities in pure water, over wide temperature and pressure ranges, especially for $\mathrm{O}_{2}$ and argon.

Figure S1 of Supporting Information presents modelling results of gas solubilities for the three main components $\left(\mathrm{N}_{2}, \mathrm{O}_{2}\right.$ and argon) of air in pure water, and it shows that CPA represents well the experimental data of gas solubilities. The experimental data and the model show that $\mathrm{N}_{2}$ has the lowest solubility values, while argon shows the largest solubility ability in pure water, with the $\mathrm{O}_{2}$ solubility being somewhat smaller compared to argon.

There are two mechanisms of the gas dissolution. These are (1) the vacancy mechanism ${ }^{32}$ (also called as insertion mechanism ${ }^{33}$ or hydrophobic mechanism ${ }^{34}$ ), i.e. the filling of interstices (vacancies) 32, 35 and (2) the solvation mechanism ${ }^{32}$ (also called as insertion-substitution mechanism ${ }^{33}$ or hydrophilic mechanism ${ }^{34}$ ), which is the substitution of water molecules in the structural framework of water ${ }^{32,65}$.

From Figures S1 and S2 of Supporting Information, it can be seen that, at different temperatures and pressures, the solubilities of $\mathrm{O}_{2}$ are about twice as high compared to $\mathrm{N}_{2}$, and in fact, this phenomenon is not unique to water ${ }^{36}$. One explanation is the "distorting effects on hydrogen-bonding network of the surrounding water" ${ }^{36-39}$. The McGowan volume of $\mathrm{N}_{2}\left(22.22 \mathrm{~cm}^{3} / \mathrm{mol}\right)$ is $21 \%$ greater than that of $\mathrm{O}_{2}(18.30$ $\left.\mathrm{cm}^{3} / \mathrm{mol}\right)^{37}$, so small hydrophobic solutes can enter the bulk water system without severely distorting the hydrogen-bonding network of the surrounding water molecules ${ }^{38-39}$. The $\mathrm{N}_{2}-\mathrm{H}_{2} \mathrm{O}$ interaction is approximately twice as high as the $\mathrm{O}_{2}-\mathrm{H}_{2} \mathrm{O}$ interaction ${ }^{38-39}$. In other words, more energy is required in order to form a cavity for $\mathrm{N}_{2}$ 
than for $\mathrm{O}_{2}$ in the aqueous solvent ${ }^{37}$. $\mathrm{N}_{2}$ causes a greater distortion of this hydrogenbonding network than $\mathrm{O}_{2}$, leading to lower solubilities of $\mathrm{N}_{2}{ }^{36}$. This explanation is based on the hydrophobic mechanism ${ }^{34}$.

Battino and Seybold ${ }^{36}$ suggest that molecular simulations could be applied to investigate this phenomenon.

From Figures S3-S5 of Supporting Information, it can be clearly seen that, with increasing temperature, the solubilities of $\mathrm{N}_{2}, \mathrm{O}_{2}$ and argon reach a minimum and then increase.

Kuenen ${ }^{40}$ pointed out that, the existence of a minimum is a common phenomenon and is not associated with the specific properties of the solvent and the dissolved gas. Moreover, the gas solubility minima are encountered also in non-aqueous solvents ${ }^{41-42}$. It has been reported ${ }^{43}$ that the minima in the solubilities of the majority of gases in water occur in the range $323-343 \mathrm{~K}$. Most studies have been done for $\mathrm{O}_{2}$. The minimum solubility of $\mathrm{O}_{2}$ in pure water is reported at $373 \mathrm{~K}^{44}$ (Pressure=0.1 MPa), $348 \mathrm{~K}^{44}$ (Pressure=10 MPa), $385 \mathrm{~K}^{45}$ (Pressure $\approx 0.7-3.5 \mathrm{MPa}$ and 7-14 MPa), approximately $373 \mathrm{~K}^{44}$ (Pressure $\approx 2-6 \mathrm{MPa}$ ), and approximately $373 \mathrm{~K}^{46-47}$ (Pressure=1-5 MPa). In these studies, it has also been found out that an increase in pressure from 0.7 to $5 \mathrm{MPa}$ hardly affects the minimum temperature point ${ }^{45-46}$, but a further increase in pressure from 7 to $10 \mathrm{MPa}$ leads to a decrease of the minimum temperature point ${ }^{48}$.

Groisman and Khomutov ${ }^{44}$ reviewed the explanations of this phenomenon. According to the works of Winkler ${ }^{49}$, the changes in the internal friction (viscosity) and density of the liquid as a function of temperature affect the solubilities of the gas in opposite ways. This leads to a minimum in the temperature variation of the solubilities of the gas in the liquid. Tammann ${ }^{43}$ presented another theoretical study, which is on the basis of the hydration theory (hydrophilic mechanism): temperature increase causes the reduction of the vacancy contribution, and also an increase of the solvation contribution. These two opposing contributions are responsible for the presence of a minimum in the curves of the temperature variation of the solubilities of $\mathrm{O}_{2}$ (as well as of other non-polar gases in water $)^{32}$. 


\subsection{Predictions of Solubilities of Gas Mixtures}

Actually, both in nature and in the chemical industry, the existence of gas mixtures is more common than the existence of single gases. Air is the most common gas mixture in nature, and air can be simplified to contain three gases, $\mathrm{N}_{2}\left(78.084 \%\right.$ by volume), $\mathrm{O}_{2}$ (20.9476\% by volume), and argon ${ }^{50}$. Gas mixtures like $\mathrm{CH}_{4}+\mathrm{CO}_{2}$ and $\mathrm{N}_{2}+\mathrm{CO}_{2}$ are common in petroleum and geological fluids ${ }^{51-53}$.

Table 1 presents the predictions of the solubilities of gas mixtures in pure water we have obtained with CPA using no interaction parameters between the gases.

Table 1. Predictive performance of CPA for the solubilities of gas mixtures in pure water.

\begin{tabular}{lllll}
\hline Gas mixture & $\mathrm{T}[\mathrm{K}]$ & $\mathrm{P}[\mathrm{MPa}]$ & $\mathrm{Np}$ & $\mathrm{RAD}(\mathrm{xGas}, \%)$ \\
\hline \multirow{2}{*}{ Air $\left(\mathrm{N}_{2}+\mathrm{O}_{2}+\mathrm{Ar}\right)$} & $273.15-343.15$ & $0.101-25.000$ & $121^{54-56}$ & $4.9($ Air $)$ \\
& $273.72-308.32$ & 0.101 & $14^{57-58}$ & $1.5^{\mathrm{a}}\left(\mathrm{O}_{2}\right)$ \\
$\mathrm{CO}_{2}+\mathrm{N}_{2}$ & $308.15-318.15$ & $8.000-16.000$ & $42^{52}$ & $2.0\left(\mathrm{CO}_{2}\right) / 8.1\left(\mathrm{~N}_{2}\right)$ \\
& 344.15 & $10.000-100.000$ & $9^{51}$ & $3.3\left(\mathrm{CH}_{4}\right) / 6.1\left(\mathrm{CO}_{2}\right)$ \\
$\mathrm{CH}_{4}+\mathrm{CO}_{2}$ & $324.00-376.20$ & $10.500-50.600$ & $21^{3}$ & $5.2\left(\mathrm{CH}_{4}\right) / 4.1\left(\mathrm{CO}_{2}\right)$ \\
\hline
\end{tabular}

a. the experimental studied are reported for $\mathrm{H}_{2} \mathrm{O}+\mathrm{Air}$, but only experimental solubilities of $\mathrm{O}_{2}$ are given.

From Table 1, it can be seen that CPA can overall predict well the solubilities of gas mixtures in pure water. Investigation of the model performance of a specific gas solubilities (e.g. the $\mathrm{O}_{2}$ solubilities for $\mathrm{H}_{2} \mathrm{O}+$ air system) is more helpful for validating the predictive ability of model. Unfortunately, there are few experimental data points for specific gas solubilities in gas mixture systems (most experimental data points present the total solubilities ${ }^{54-56}$, and only few data points give solubilities of the specific gases ${ }^{57-58}$ ). For further studies of air solubilities, more experimental data of specific gas are suggested. 
Figures 1 and S6 of Supporting Information show the solubilities of air in pure water. From these two figures, it can be seen that CPA can predict well the gas solubilities of air.

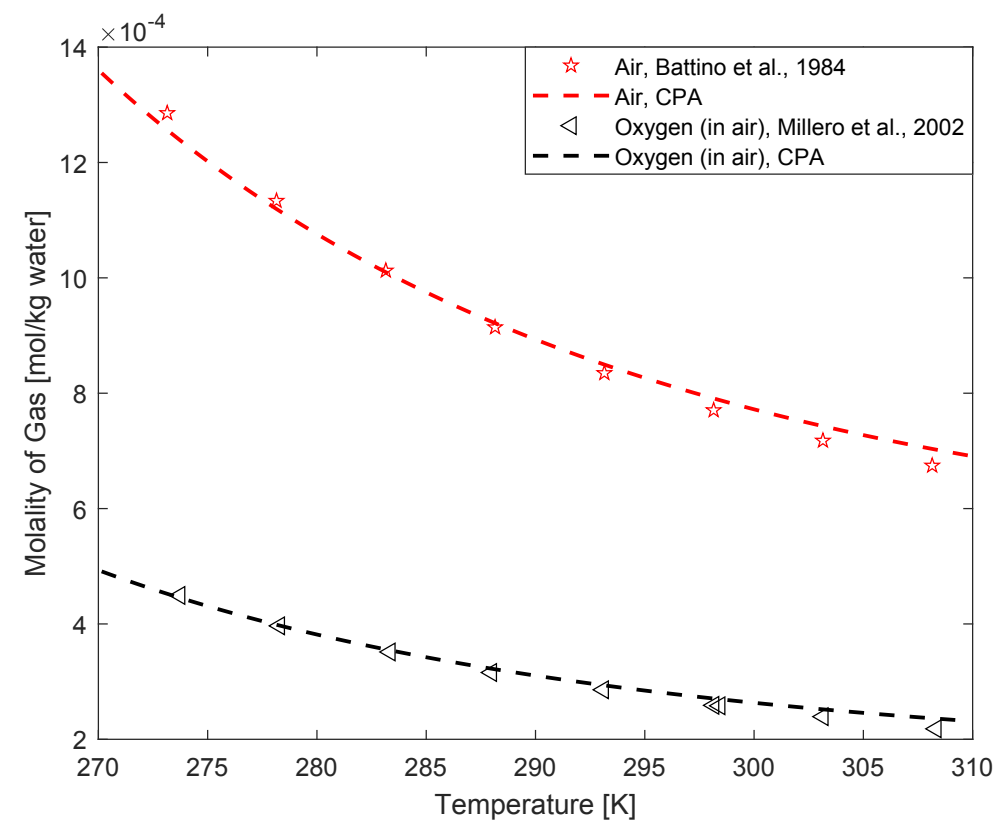

Figure 1. Solubilities of air and $\mathrm{O}_{2}$ (in air) in pure water at atmospheric pressure ${ }^{56-57}$.

Figure 1 shows gas solubilities of air and $\mathrm{O}_{2}$ (in air) in pure water at atmospheric pressure. The solubilities of air $\left(\mathrm{N}_{2}+\mathrm{O}_{2}+\operatorname{argon}\right)$ are almost three times of those of $\mathrm{O}_{2}$, which is consistent with Figure $\mathrm{S} 1$ of Supporting Information. For the $\mathrm{H}_{2} \mathrm{O}+$ air system, the volume fraction $\left(\mathrm{N}_{2}: \mathrm{O}_{2} \approx 78.1: 20.9\right)$ and solubility abilities of pure-gas $\left(\mathrm{N}_{2}: \mathrm{O}_{2} \approx\right.$ $1: 2)$ result in the mole fraction of specific gas (in air) in pure water $\left(\mathrm{N}_{2}: \mathrm{O}_{2} \approx 2: 1\right.$ ).

Figure S6 of Supporting Information shows the air solubilities in pure water at different temperatures and pressures. The difference in air solubilities between different temperatures becomes larger with increasing pressure, and this trend seems smaller at high temperature.

From the above results, it can be seen that CPA can predict satisfactorily the solubilities 
of gas mixtures without interaction parameters between the gases.

\section{Gas Dissolution in Aqueous Electrolyte Solutions}

When electrolyte solutions are considered, the electrostatic terms (DH and Born) are used as well as the HV-NRTL infinite pressure mixing rule and therefore the electrolyte CPA (e-CPA) EoS is applied.

\subsection{Correlations of Solubilities of Single-Gas in Aqueous Single-Salt Solutions}

Modeling of solubilities of single-gas in aqueous single-salt solutions is a correlation task, in which the cation/anion-gas interaction parameters are obtained by fitting the experimental data of gas solubility.

In our previous works, the solubilities of $\mathrm{CH}_{4}$ and $\mathrm{CO}_{2}$ in aqueous electrolyte solutions are studied, as well as the solubilities of $\mathrm{N}_{2}$ in an aqueous $\mathrm{NaCl}$ solution. In this section, solubility studies of $\mathrm{N}_{2}, \mathrm{O}_{2}$, and argon in aqueous electrolyte solutions are presented. It should be pointed out that, in some experimental works, the unit of salt concentration is molarity (mol/L solution), but in our calculations, we convert molarity to molality (mol/kg water) before modeling (by using experimental correlations of the liquid density $\left.{ }^{59}\right)$.

Although $\mathrm{NaCl}, \mathrm{KCl}$ and $\mathrm{CaCl}_{2}$ are common electrolytes in the chemical industry and geological fluids, investigation of other electrolytes is helpful to systematically study the gas solubilities in aqueous electrolyte solutions and thus such systems are useful for evaluating the capabilities of the model. In this work, we have considered many systems where experimental data have been found in the literature.

Table 2 presents the cation/anion- $\mathrm{N}_{2}$ interaction parameters and the modeling performance of e-CPA for $\mathrm{N}_{2}$ solubilities in aqueous electrolyte solutions.

Table 2. Cation/anion- $\mathrm{N}_{2}$ interaction parameters and performance of e-CPA for the 
correlation of $\mathrm{N}_{2}$ solubilities.

\begin{tabular}{|c|c|c|c|c|c|c|c|c|}
\hline Salt & $\mathrm{T}[\mathrm{K}]$ & $\mathrm{P}[\mathrm{MPa}]$ & $\mathrm{m}^{\mathrm{b}}$ & $\mathrm{Np}$ & $\begin{array}{l}\Delta U_{i j}^{r e f} / R \\
{[\mathrm{~K}]}\end{array}$ & $\begin{array}{l}T_{\Delta U_{i j}} \\
{[\mathrm{~K}]}\end{array}$ & $\begin{array}{l}\omega_{\Delta U_{i j}} \\
{[\mathrm{~K}]}\end{array}$ & $\begin{array}{l}\text { RAD } \\
{[\%]}\end{array}$ \\
\hline $\mathrm{KCl}$ & $273.15-513.15$ & 9.810 & $0.0-2.1$ & $24^{60}$ & 2017.9 & 200.7 & 505.4 & 8.1 \\
\hline $\mathrm{CaCl}_{2}$ & 303.15 & $1.240-7.600$ & $0.5-4.0$ & $18^{7}$ & 476.8 & 201.6 & 624.1 & 9.7 \\
\hline $\mathrm{BaCl}_{2}$ & $278.15-298.15$ & $0.101^{\mathrm{a}}$ & $0.0-0.8$ & $35^{61}$ & 1578.4 & 218.7 & 9980.8 & 2.5 \\
\hline $\mathrm{Na}_{2} \mathrm{SO}_{4}$ & $298.15-303.15$ & $0.101-6.980$ & $0.0-2.2$ & $21^{7,62}$ & 2053.5 & 200.5 & -6210.8 & 6.1 \\
\hline $\mathrm{MgSO}_{4}$ & 303.15 & $1.520-6.980$ & $1.3-2.6$ & $9^{7}$ & $1313.1^{\mathrm{c}}$ & - & - & 11.8 \\
\hline
\end{tabular}

a. partial pressure of $\mathrm{N}_{2} ;$ b. molality of salt [mol/ $\mathrm{kg}$ water]; c. temperature-independent cation/anion-gas interaction parameter due to lack of plentiful experimental data.

The uncertainty of the adjustable parameters is 0.05 .

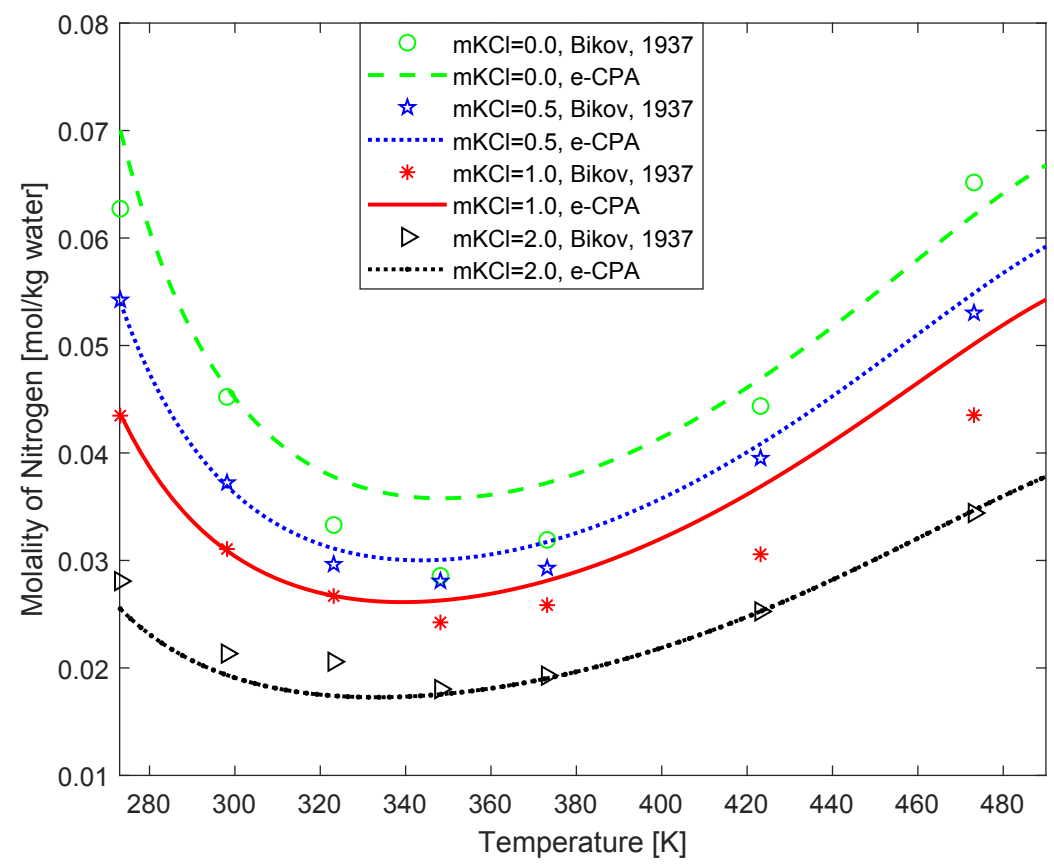

Figure 2. Solubilities of $\mathrm{N}_{2}$ in aqueous $\mathrm{KCl}$ solution at $9.81 \mathrm{MPa}^{60}$.

Figure 2 shows the $\mathrm{N}_{2}$ solubilities in aqueous $\mathrm{KCl}$ solution at 9.81 $\mathrm{MPa}$. The presence of $\mathrm{KCl}$ decreases the $\mathrm{N}_{2}$ solubilities in water, in other words, $\mathrm{KCl}$ shows significant salting-out effects on $\mathrm{N}_{2}$ in water, and the salting-out effects increase with increasing salt molality. It can also be seen from Figure 2 that the phenomenon of a minimum 
solubility is also observed in electrolyte systems.

It is of interest to compare the salting-out effects on $\mathrm{N}_{2}$ between different salts. Figure 3 shows the solubilities of $\mathrm{N}_{2}$ in different electrolyte solutions.

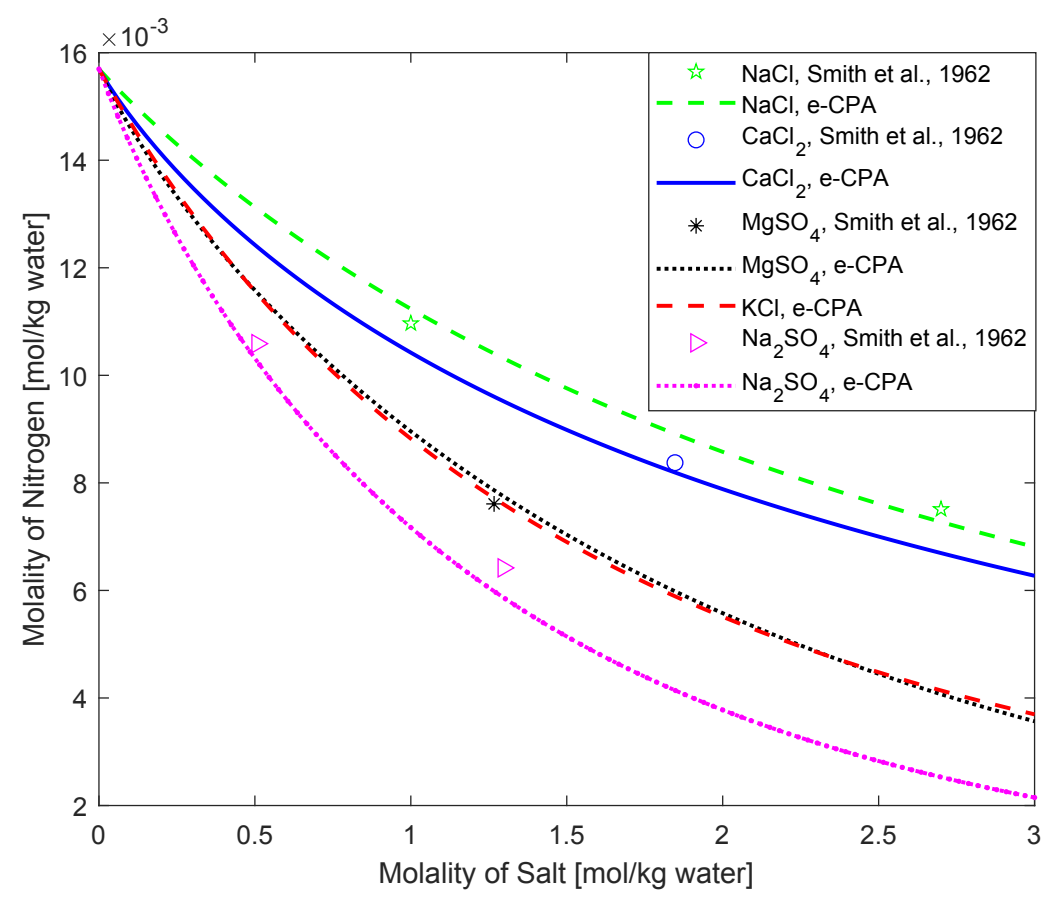

Figure 3. Solubilities of $\mathrm{N}_{2}$ in different aqueous solutions at different pressures at 303.15 $\mathrm{K}$ and $2.50 \mathrm{MPa}^{7}$.

As can be seen from Figure 3, different salts have different salting-out effects, and the difference comes from the different ion hydration abilities. An ion with higher charge density (i.e. higher charge and smaller ion size) has higher ion hydration abilities. The ion hydration can reduce the number of the water molecular cavities (which can catch gas molecules), leading to lower gas solubilities. Figure 3 shows that the salting-out effects of different salts follow a sequence of $\mathrm{NaCl}<\mathrm{CaCl}_{2}<\mathrm{MgSO}_{4} \approx \mathrm{KCl}<\mathrm{Na}_{2} \mathrm{SO}_{4}$ with the same molality. In our previous work, the salting-out effects on $\mathrm{CO}_{2}$ follow a sequence of $\mathrm{KCl}<\mathrm{NaCl}<\mathrm{CaCl}_{2}<\mathrm{Na}_{2} \mathrm{SO}_{4}$ with the same molality. An unexpected thing (due to ion hydration abilities) is that, $\mathrm{KCl}$ does not show the weakest salting-out effects. The reasons for this may be due to the interaction between $\mathrm{N}_{2}$ and $\mathrm{KCl}$, or the 
experimental data being in narrow pressure range cannot reflect the extensive saltingout effects. For a more accurate explanation, experimental data over wider temperature ranges are needed.

Table 3 presents the cation/anion- $\mathrm{O}_{2}$ interaction parameters and modeling performance for $\mathrm{O}_{2}$ solubilities. The experimental data are available over wide salt molality ranges, but in narrow temperature ranges and only available at atmospheric pressure. For most systems, e-CPA yields good agreement with experimental data, while the deviations for $\mathrm{KCl}$ and $\mathrm{CaCl}_{2}$ systems are a little bit larger. Figures 4-8 show graphically the results for some systems.

Table 3. Cation/anion- $\mathrm{O}_{2}$ interaction parameters and performance of e-CPA for the correlation of $\mathrm{O}_{2}$ solubilities.

\begin{tabular}{|c|c|c|c|c|c|c|c|c|}
\hline Salt & $\mathrm{T}[\mathrm{K}]$ & $\begin{array}{l}\mathrm{P}^{\mathrm{a}} \\
{[\mathrm{MPa}]}\end{array}$ & $\mathrm{m}^{\mathrm{b}}$ & $\mathrm{Np}$ & $\begin{array}{l}\Delta U_{i j}^{r e f} / R \\
{[\mathrm{~K}]}\end{array}$ & $\begin{array}{l}T_{\Delta U_{i j}} \\
{[\mathrm{~K}]}\end{array}$ & $\omega_{\Delta U_{i j}}[\mathrm{~K}]$ & $\begin{array}{l}\text { RAD } \\
{[\%]}\end{array}$ \\
\hline $\mathrm{NaCl}$ & $273.15-310.15$ & 0.101 & $0.0-5.6$ & $66^{9,63-69}$ & 1401.1 & 399.9 & -4761.1 & 3.8 \\
\hline $\mathrm{KCl}$ & $273.15-310.15$ & 0.101 & $0.0-4.7$ & $53^{9,66-68,70}$ & 1256.3 & 288.9 & 9989.7 & 7.9 \\
\hline $\mathrm{CaCl}_{2}$ & $298.15-310.15$ & 0.101 & $0.0-5.2$ & $34^{9,68,70}$ & 823.5 & 151.9 & 2111.1 & 7.4 \\
\hline $\mathrm{MgCl}_{2}$ & $273.15-310.15$ & 0.101 & $0.0-4.3$ & $37^{9,67-68,70}$ & 629.5 & 291.5 & 9998.1 & 4.8 \\
\hline $\mathrm{LiCl}$ & $273.15-293.15$ & 0.101 & $0.0-2.3$ & $8^{67}$ & $918.9^{c}$ & - & - & 4.3 \\
\hline $\mathrm{Na}_{2} \mathrm{SO}_{4}$ & $288.15-310.15$ & 0.101 & $0.0-1.9$ & $41^{9,62,68}$ & 2117.1 & 548.9 & -9984.9 & 2.5 \\
\hline $\mathrm{K}_{2} \mathrm{SO}_{4}$ & $288.15-310.15$ & 0.101 & $0.2-0.6$ & $199,68-69$ & 2165.5 & 334.5 & -138.4 & 2.2 \\
\hline $\mathrm{MgSO}_{4}$ & $288.15-310.15$ & 0.101 & $0.0-2.7$ & $59^{9}, 68,70$ & 1792.5 & 530.1 & -4504.3 & 3.8 \\
\hline $\mathrm{NaNO}_{3}$ & 298.15 & 0.101 & $0.0-6.2$ & $9^{70}$ & $1400.0^{c}$ & - & - & 1.6 \\
\hline $\mathrm{Ca}\left(\mathrm{NO}_{3}\right)_{2}$ & 298.15 & 0.101 & $0.0-2.7$ & $8^{70}$ & $987.6^{c}$ & - & - & 2.2 \\
\hline $\mathrm{NaOH}$ & $288.15-308.15$ & 0.101 & $0.0-6.6$ & $38^{69-70}$ & 1486.0 & 487.4 & -4994.9 & 3.1 \\
\hline $\mathrm{KOH}$ & $288.15-298.15$ & 0.101 & $0.6-1.2$ & $8^{69}$ & $1264.4^{\mathrm{c}}$ & & & 0.8 \\
\hline
\end{tabular}

a. partial pressure of $\mathrm{O}_{2} ;$ b. molality of salt [mol/kg water]; c. temperature-independent cation/anion-gas interaction parameter due to lack of plentiful experimental data. 
The uncertainty of the adjustable parameters is 0.05 .

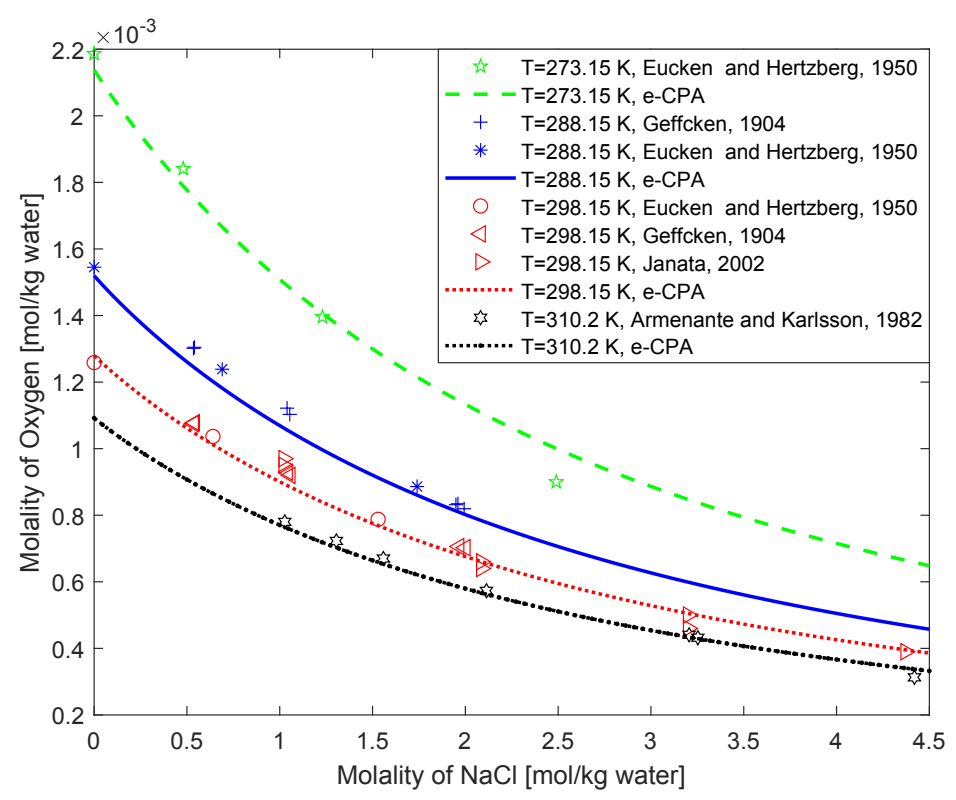

Figure 4. Solubilities of $\mathrm{O}_{2}$ in aqueous $\mathrm{NaCl}$ solutions at atmospheric pressure ${ }^{65,67-69}$.

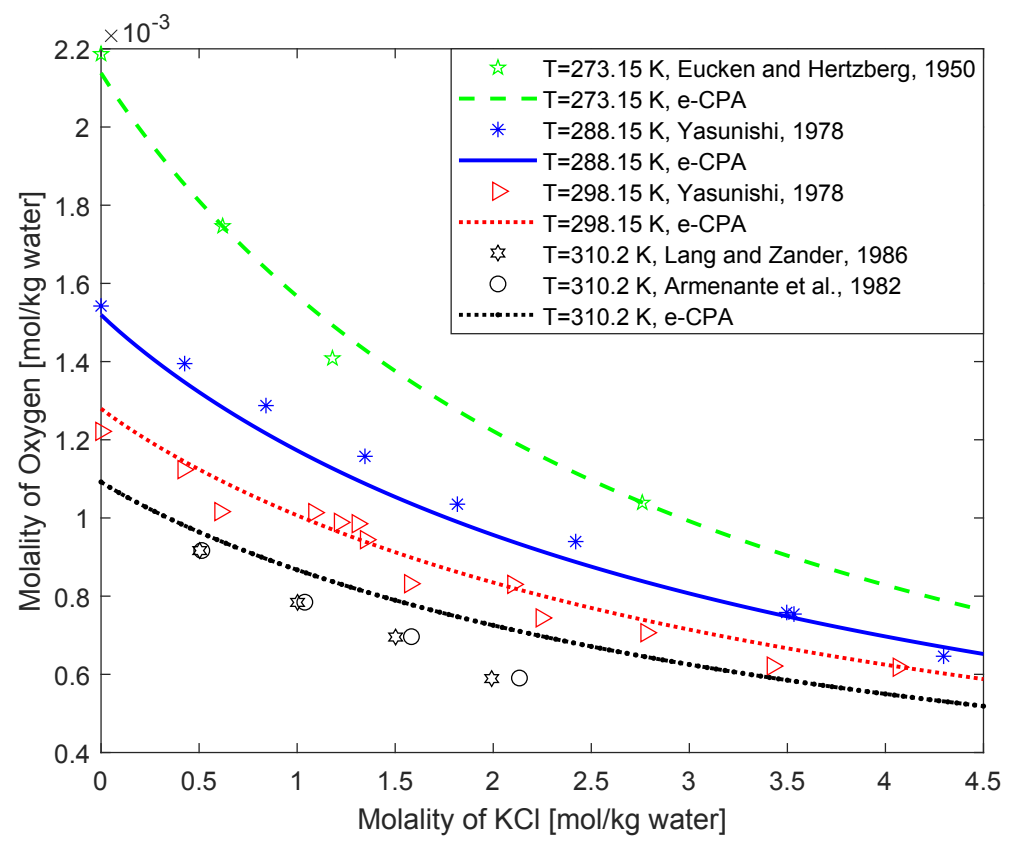

Figure 5. Solubilities of $\mathrm{O}_{2}$ in aqueous $\mathrm{KCl}$ solutions at atmospheric pressure 9 , 67-68, 70.

Figures 4 and 5 show the modeling results of $\mathrm{O}_{2}$ solubilities in aqueous solutions of $\mathrm{NaCl}$ and $\mathrm{KCl}$. The $\mathrm{O}_{2}$ solubilities decrease with increasing temperature (in the 
experimental temperature ranges), and $\mathrm{NaCl}$ and $\mathrm{KCl}$ both show significant salting-out effects on $\mathrm{O}_{2}$ in water.

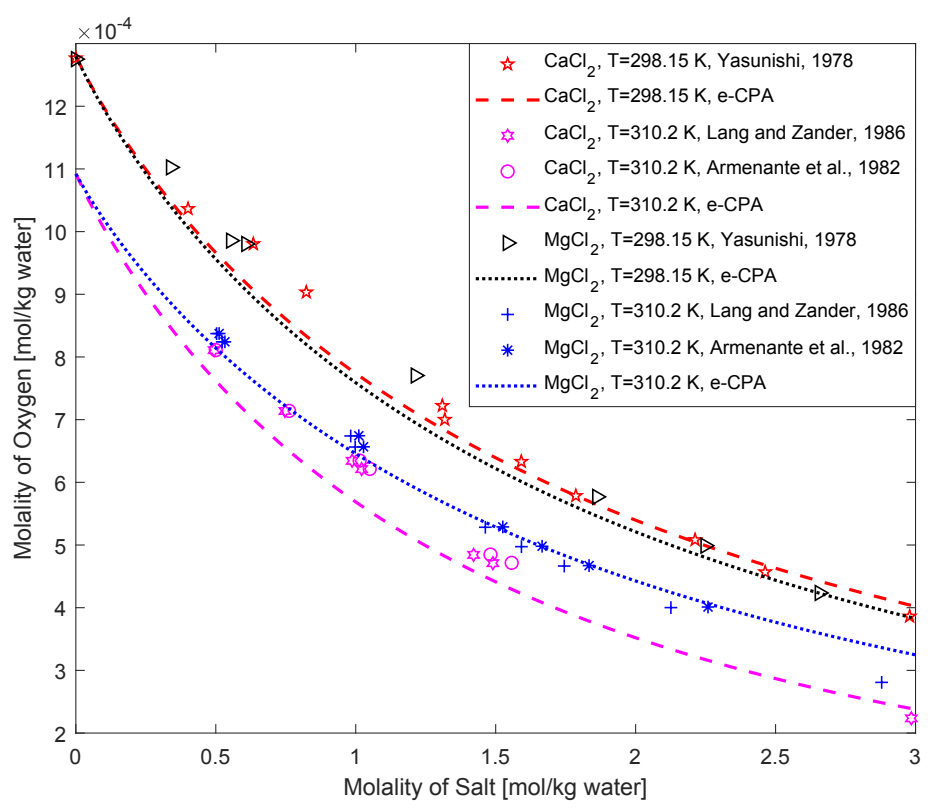

Figure 6. Solubilities of $\mathrm{O}_{2}$ in aqueous solutions of $\mathrm{CaCl}_{2}$ and $\mathrm{MgCl}_{2}$ at atmospheric pressure and different temperatures $9,68,70$.

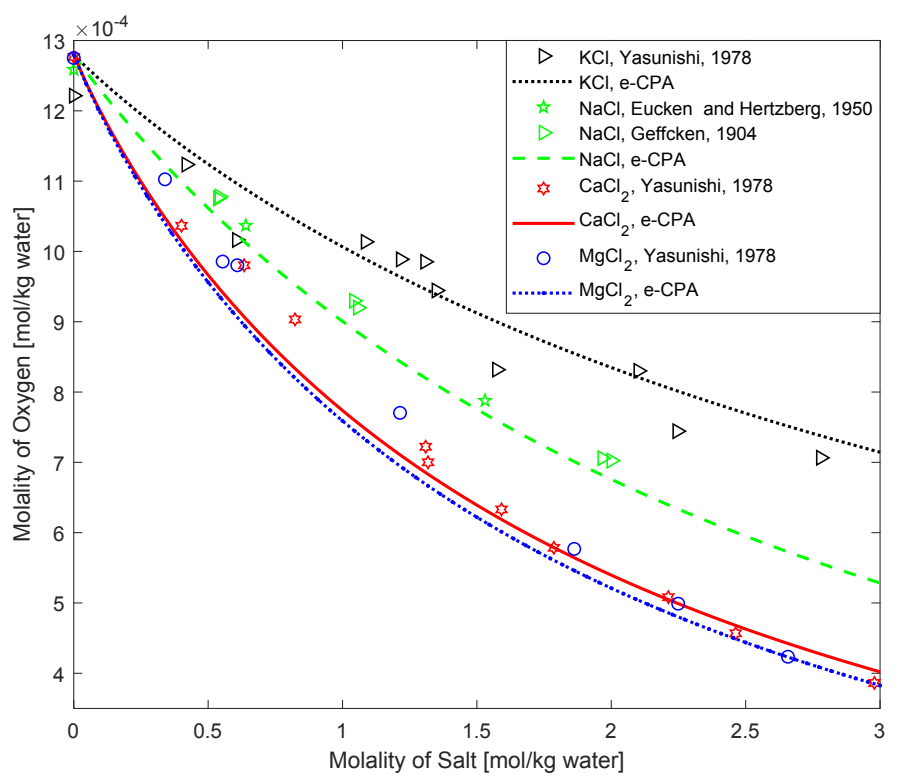

Figure 7. Solubilities of $\mathrm{O}_{2}$ in aqueous solutions of chloride salts at $298.15 \mathrm{~K}$ and atmospheric pressure ${ }^{67,69-70}$. 


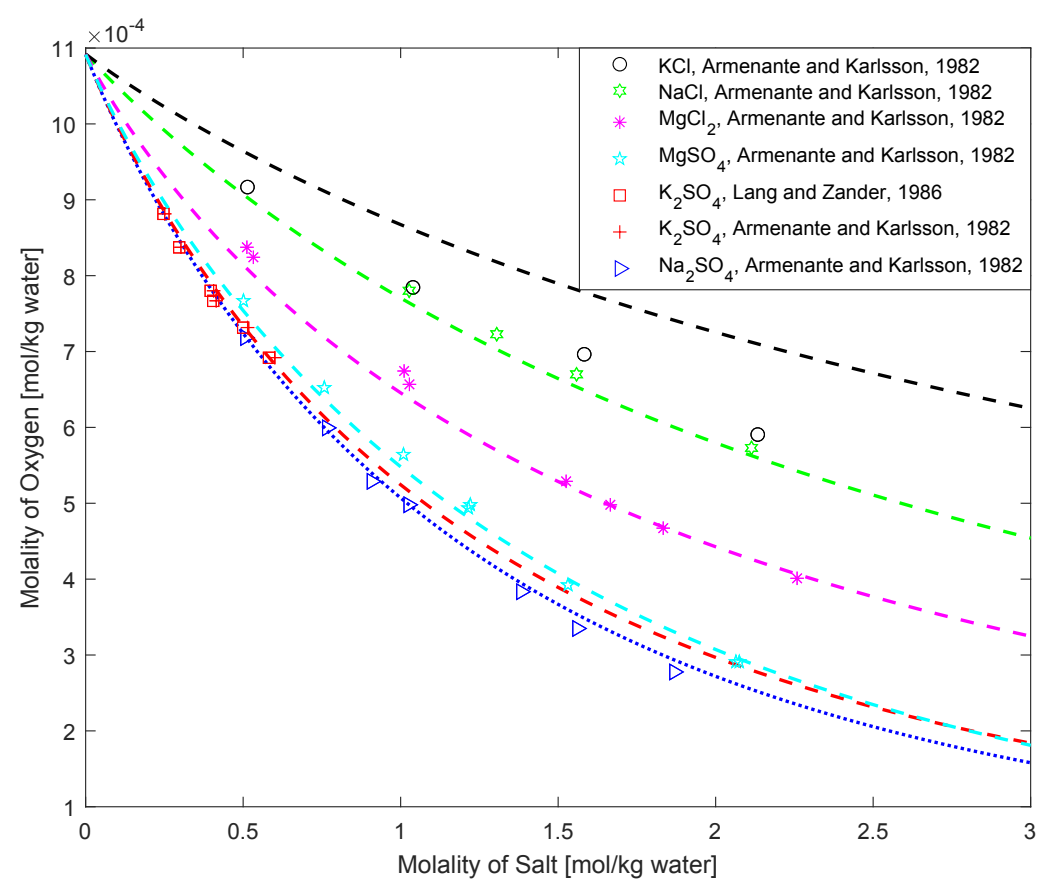

Figure 8. Solubilities of $\mathrm{O}_{2}$ in aqueous solutions of different salts at $310.2 \mathrm{~K}$ and atmospheric pressure ${ }^{9,68}$.

Figures 6-8 show the modeling results for $\mathrm{O}_{2}$ solubilities in different aqueous electrolyte solutions. Similar to other gas systems, different salts show different saltingout effects on $\mathrm{O}_{2}$ in water. Figure 6 shows the modeling results of $\mathrm{CaCl}_{2}$ and $\mathrm{MgCl}_{2}$ systems, where these two salts have similar salting-out effects on $\mathrm{O}_{2}$ in water. The Pauling Radius of $\mathrm{Ca}^{2+}$ is $0.99 \AA$, while the Pauling Radius of $\mathrm{Mg}^{2+}$ is $0.65 \AA$. This implies that $\mathrm{Mg}^{2+}$ has stronger ion hydration effects than that of $\mathrm{Ca}^{2+}$, but $\mathrm{CaCl}_{2}$ and $\mathrm{MgCl}_{2}$ both have two $\mathrm{Cl}^{-}$, so, the contributions from anion also need to be considered. The combined effects of cation and anion resulted in $\mathrm{CaCl}_{2}$ and $\mathrm{MgCl}_{2}$ have similar salting-out effects.

From Figure 7, it can be seen that the salting-out effects on $\mathrm{O}_{2}$ in water at $298.15 \mathrm{~K}$ follow a sequence of $\mathrm{KCl}<\mathrm{NaCl}<\mathrm{CaCl}_{2} \approx \mathrm{MgCl}_{2}$ with the same molality. This order is the same as our previous study for $\mathrm{CO}_{2}{ }^{23}$.

In Figure 8, the salts with two cations $\left(\mathrm{K}_{2} \mathrm{SO}_{4}\right.$ and $\left.\mathrm{Na}_{2} \mathrm{SO}_{4}\right)$ have stronger salting-out effects than the corresponding monovalent salts $(\mathrm{KCl}$ and $\mathrm{NaCl})$, because cations contribute more than anions to ion hydration. It can also be observed that $\mathrm{MgSO}_{4}$ has 
stronger salting-out effects than $\mathrm{MgCl}_{2}$; this phenomenon may be explained by an additional equilibrium of dissolution of $\mathrm{SO}_{4}{ }^{2-}$ and the difference of the ion-association between $\mathrm{MgCl}_{2}$ and $\mathrm{MgSO}_{4}$.

Table 4 presents cation/anion-argon interaction parameters and modeling performance for argon solubilities. As in the case with $\mathrm{O}_{2}$, the experimental data cover wide salt molality ranges, but only narrow temperature and pressure ranges. The e-CPA modeling results are in good agreement with experimental data for these systems. Figures 9-13 show graphically the results for some systems.

Table 4. Cation/anion-argon interaction parameters and performance of e-CPA for the correlation of argon solubilities.

\begin{tabular}{|c|c|c|c|c|c|c|c|c|}
\hline Salt & $\mathrm{T}[\mathrm{K}]$ & $\begin{array}{l}\mathrm{P} \\
{[\mathrm{MPa}]}\end{array}$ & $\mathrm{m}^{\mathrm{b}}$ & $\mathrm{Np}$ & $\begin{array}{l}\Delta U_{i j}^{r e f} / R \\
{[\mathrm{~K}]}\end{array}$ & $\begin{array}{l}T_{\Delta U_{i j}} \\
{[\mathrm{~K}]}\end{array}$ & $\begin{array}{l}\omega_{\Delta U_{i j}} \\
{[\mathrm{~K}]}\end{array}$ & $\begin{array}{l}\text { RAD } \\
{[\%]}\end{array}$ \\
\hline $\mathrm{NaCl}$ & $273.15-313.15$ & $0.101^{\mathrm{a}}$ & $0.0-6.0$ & $52^{8,67,71-73}$ & 1227.5 & 539.5 & 4998.5 & 4.3 \\
\hline $\mathrm{KCl}$ & $278.15-303.15$ & $0.101^{\mathrm{a}}$ & $0.0-4.6$ & $18^{8,71,73}$ & 1339.8 & 325.3 & 155.6 & 4.1 \\
\hline $\mathrm{CaCl}_{2}$ & 298.15 & $0.101^{\mathrm{a}}$ & $0.0-5.4$ & $3^{71}$ & $281.2^{\mathrm{c}}$ & - & - & 2.1 \\
\hline $\mathrm{MgCl}_{2}$ & 298.15 & $0.101^{\mathrm{a}}$ & $0.0-5.0$ & $3^{71}$ & $-72.3^{c}$ & - & - & 2.1 \\
\hline $\mathrm{LiCl}$ & $278.15-313.15$ & $0.101^{\mathrm{a}}$ & $0.0-6.8$ & $52^{8,71-73}$ & 574.0 & 329.6 & 4942.2 & 4.1 \\
\hline $\mathrm{RbCl}$ & $283.15-313.15$ & 0.101 & $0.0-2.4$ & $23^{72}$ & 1294.6 & 342.2 & -100.7 & 3.3 \\
\hline $\mathrm{NaBr}$ & 303.15 & 0.101 & $0.0-2.0$ & $4^{8}$ & $1296.7^{c}$ & - & - & 2.3 \\
\hline $\mathrm{KBr}$ & $278.15-313.15$ & 0.101 & $0.0-2.1$ & $34^{72-73}$ & 1279.2 & 266.6 & -3498.0 & 2.6 \\
\hline $\mathrm{CsBr}$ & $283.15-313.15$ & 0.101 & $0.0-2.4$ & $24^{72}$ & 1235.0 & 260.0 & -110.7 & 3.6 \\
\hline $\mathrm{SrCl}_{2}$ & 298.15 & $0.101^{\mathrm{a}}$ & $0.0-3.6$ & $3^{71}$ & $671.6^{\mathrm{c}}$ & - & - & 4.4 \\
\hline $\mathrm{BaCl}_{2}$ & 298.15 & $0.101^{\mathrm{a}}$ & $0.0-1.7$ & $3^{71}$ & $1335.5^{c}$ & - & - & 4.7 \\
\hline $\mathrm{NaI}$ & $278.15-313.15$ & 0.101 & $0.0-3.9$ & $48^{8,72-73}$ & 1179.8 & 268.3 & -2.7 & 5.9 \\
\hline KI & $278.15-313.15$ & 0.101 & $0.0-4.0$ & $45^{72-73}$ & 1399.0 & 250.4 & -17.4 & 6.0 \\
\hline $\mathrm{KOH}$ & $288.15-298.15$ & $0.101^{\mathrm{a}}$ & $0.6-1.2$ & $8^{69}$ & $1659.4^{\mathrm{c}}$ & - & - & 2.0 \\
\hline
\end{tabular}

a. partial pressure of argon; b. molality of salt [mol/kg water]; c. temperature- 
independent cation/anion-gas interaction parameter due to lack of plentiful experimental data.

The uncertainty of the adjustable parameters is 0.05 .

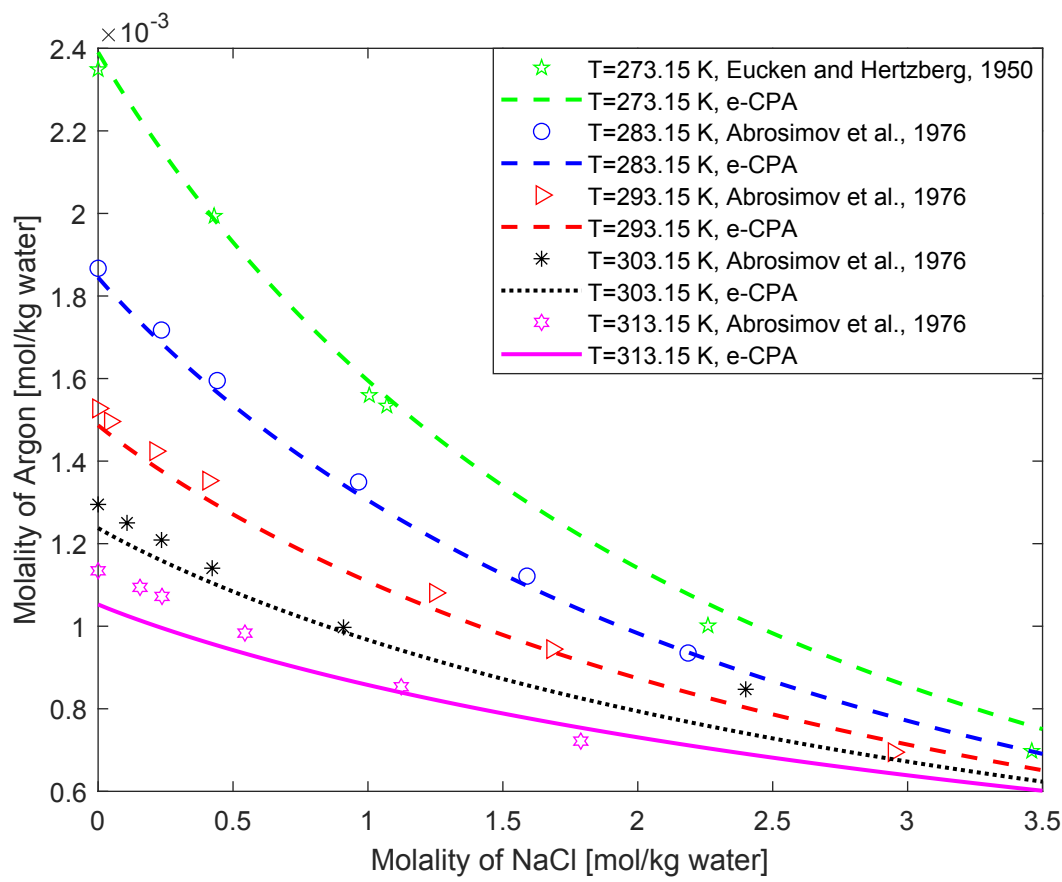

Figure 9. Solubilities of argon in aqueous $\mathrm{NaCl}$ solutions at atmospheric pressure ${ }^{67,72}$.

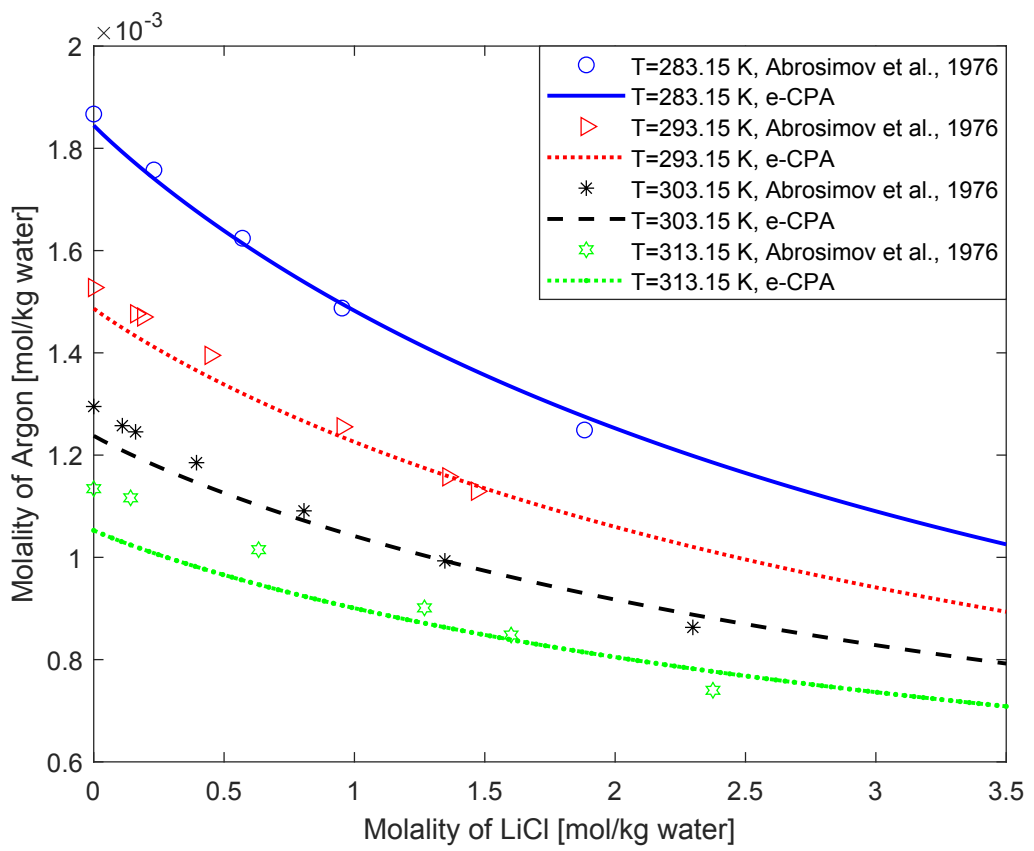

Figure 10. Solubilities of argon in aqueous $\mathrm{LiCl}$ solutions at atmospheric pressure ${ }^{72}$. 


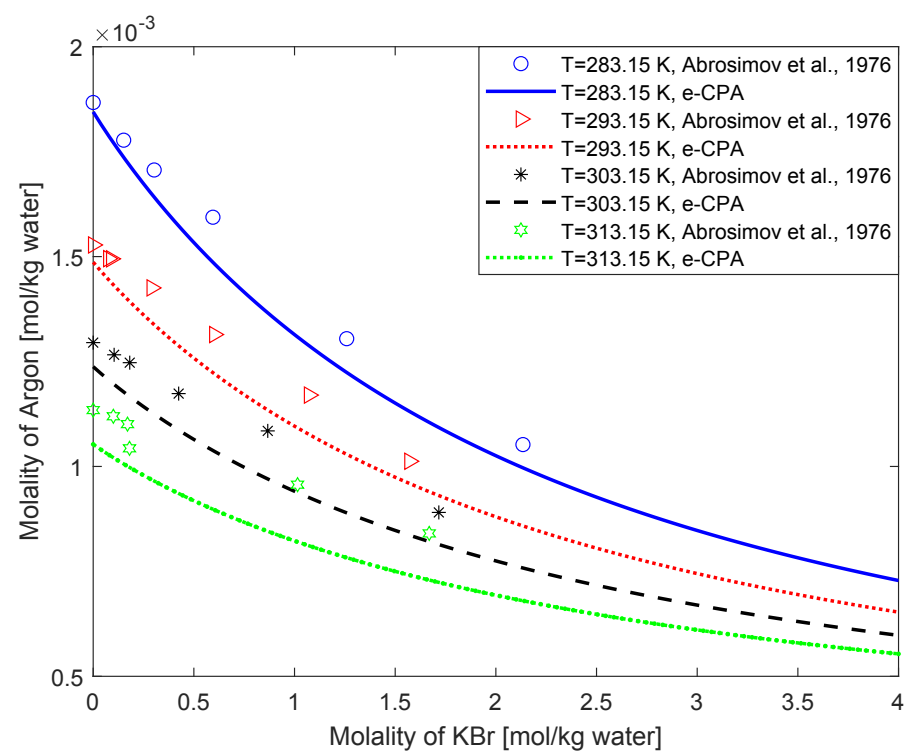

Figure 11. Solubilities of argon in aqueous $\mathrm{KBr}$ solutions at atmospheric pressure $^{72}$.

Figures 9-11 show the modeling results of argon solubilities in aqueous solutions of $\mathrm{NaCl}, \mathrm{LiCl}$ and $\mathrm{KBr}$ respectively. It can be seen that e-CPA can correlate well the argon solubilities in these systems. These salts show significant salting-out effects on argon in water.

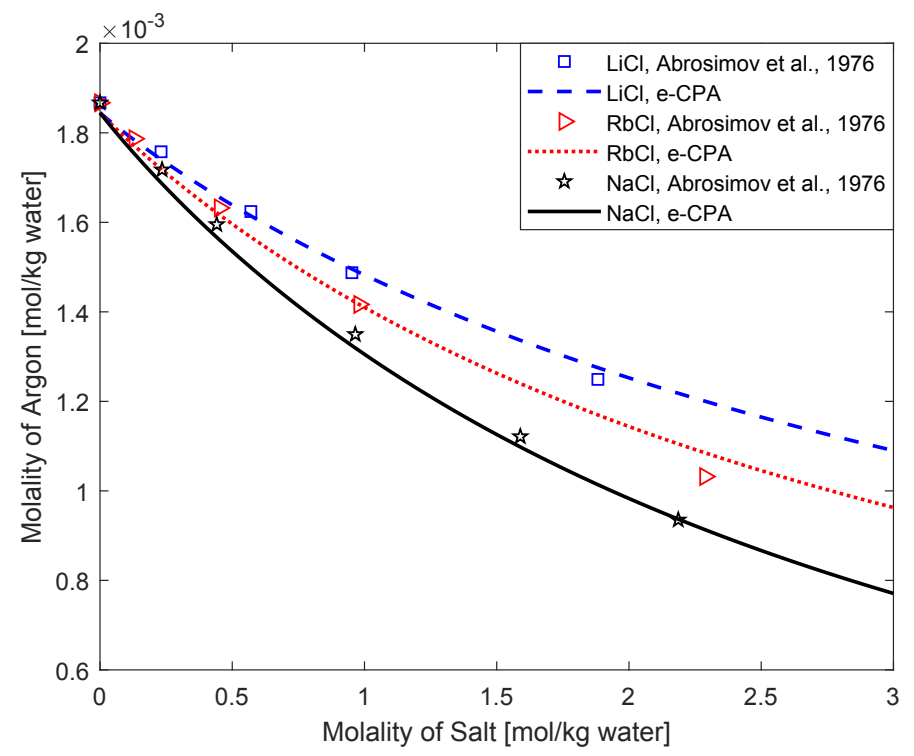

Figure 12. Solubilities of argon in aqueous solutions of chloride salts at $283.15 \mathrm{~K}$ and 
atmospheric pressure $^{72}$.

Figure 12 shows the modeling results of argon solubilities in aqueous solutions of three chloride salts. The Pauling radii of $\mathrm{Rb}^{+}, \mathrm{Na}^{+}$and $\mathrm{Li}^{+}$are $1.48 \AA, 0.95 \AA$ and $0.6 \AA$ respectively. According to the ion hydration ability, the salting-out effects on argon should follow a sequence of $\mathrm{RbCl}<\mathrm{NaCl}<\mathrm{LiCl}$ with the same molality. But the experimental data show that the salting-out effects on argon follow the sequence of $\mathrm{LiCl}<\mathrm{RbCl}<\mathrm{NaCl}$ with the same molality, that is to say $\mathrm{LiCl}$ does not show strongest salting-out effects as expected. A possible explanation is that the mean ionic activity coefficients of $\mathrm{LiCl}$ show a special phenomenon ${ }^{74}$ i.e. at moderate-high salt molality ranges, the mean ionic activity coefficients of $\mathrm{LiCl}$ do not increase as the salt molality increasing, as those of other salts do. This phenomenon may be caused by ionassociation. Ion-association reduces the number of free ions, and this may cause unexpected salting-out effects.

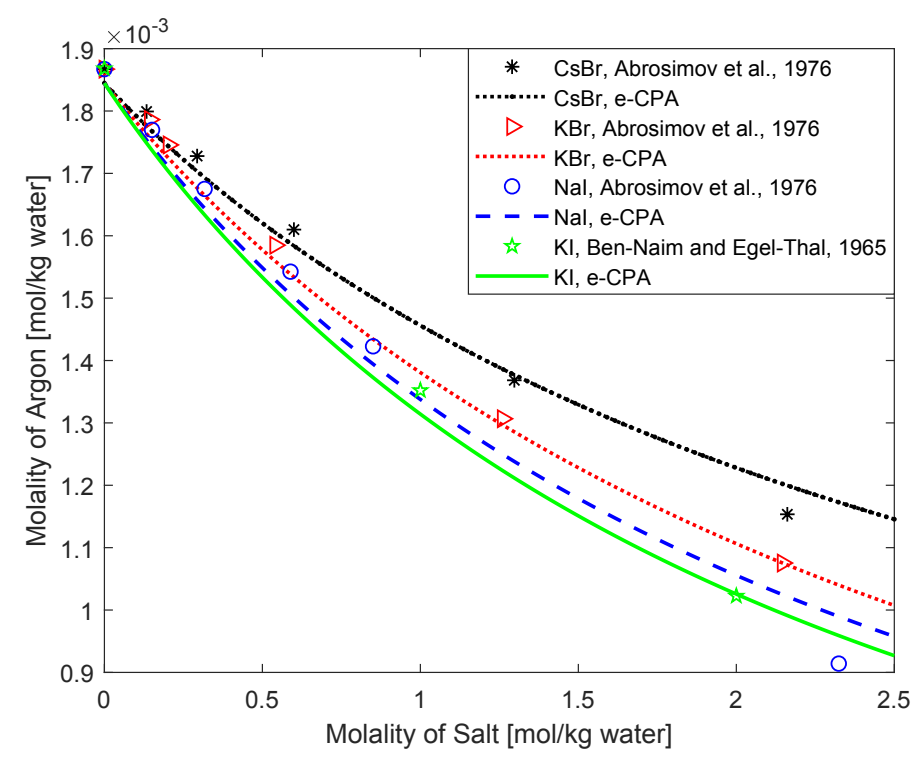

Figure 13. Solubilities of argon in aqueous solutions of bromine salts and iodine salts at $283.15 \mathrm{~K}$ and atmospheric pressure ${ }^{72-73}$.

Figure 13 shows the modeling results of argon solubilities in aqueous solutions of bromine and iodine salts. These salts also show significant salting-out effects on argon 
in water. The salting-out effects of $\mathrm{KBr}$ are more pronounced than those of $\mathrm{CsBr}$, because the Pauling radius of $\mathrm{K}^{+}(1.33 \AA)$ is smaller than that of $\mathrm{Cs}^{+}(1.69 \AA)$, which means that $\mathrm{KBr}$ has stronger ion hydration abilities than $\mathrm{CsBr}$. As expected, $\mathrm{NaI}$ (with Pauling radius $=0.95 \AA$ for $\mathrm{Na}^{+}$) has higher salting-out effects than $\mathrm{KI}$ (with Pauling radius $=1.33 \AA$ for $\mathrm{K}^{+}$), but this cannot be seen from the experimental data. The few experimental data points available show that $\mathrm{NaI}$ and $\mathrm{KI}$ have very similar salting-out effects on argon in water.

\subsection{Predictions of Solubilities of Air in Aqueous Solutions of Single-Salt}

In this sub-section, we present the prediction of solubilities of Air in aqueous singlesalt solutions for the systems for which experimental data are available. No further adjustable parameters are introduced between gases, i.e. these results are pure predictions.

Table 5 shows the temperature-pressure-molality ranges of experimental data, as well as the deviations. The results from Table 5 show that e-CPA can predict in good agreement with the experimental data the air solubilities in aqueous single-salt solutions. Most experimental works are presented at atmosphere pressure, and most experimental works only give the liquid mole fraction of $\mathrm{O}_{2}$.

Table 5. Predictive performance of e-CPA for air solubilities in aqueous single-salt solutions.

\begin{tabular}{llllll}
\hline Salt & $\mathrm{T}[\mathrm{K}]$ & $\mathrm{P}[\mathrm{MPa}]$ & $\mathrm{m}^{\mathrm{a}}$ & $\mathrm{Np}$ & $\mathrm{RAD}[\%]$ \\
\hline $\mathrm{NaCl}$ & $273.19-318.54$ & 0.101 & $0.0-6.0$ & $182^{57-58,75-76}$ & $6.1^{\mathrm{b}}$ \\
& $298.15-338.15$ & $6.900-24.300$ & $0.0-6.0$ & $88^{55}$ & 4.3 \\
$\mathrm{KCl}$ & $278.15-318.15$ & 0.101 & $0.0-5.1$ & $59^{75-77}$ & $5.1^{\mathrm{b}}$ \\
$\mathrm{CaCl}_{2}$ & 298.15 & 0.101 & $0.0-3.0$ & $14^{75-76}$ & $5.7^{\mathrm{b}}$ \\
$\mathrm{Na}_{2} \mathrm{SO}_{4}$ & $278.3-318.3$ & 0.101 & $0.0-2.6$ & $92^{57-58,76,78}$ & $3.9^{\mathrm{b}}$ \\
$\mathrm{MgSO}_{4}$ & $278.08-318.24$ & 0.101 & $0.0-2.9$ & $75^{57-58}$ & $3.7^{\mathrm{b}}$ \\
\hline
\end{tabular}

a. molality of salt [mol/kg water]; b. the experimental works are made for $\mathrm{Air}+\mathrm{H}_{2} \mathrm{O}$, but 
only solubilities of $\mathrm{O}_{2}$ is given.

There are no cation/anion-argon interaction parameters for $\mathrm{Na}_{2} \mathrm{SO}_{4}$ and $\mathrm{MgSO}_{4}$, and the volume fraction of argon is very small in air. Therefore, we simplify air to $\mathrm{N}_{2}(79 \%$ by volume $)+\mathrm{O}_{2}(21 \%$ by volume $)$ in the calculations of these salts ${ }^{79}$, that is, the $\mathrm{H}_{2} \mathrm{O}+$ air $+\mathrm{Na}_{2} \mathrm{SO}_{4}$ and $\mathrm{H}_{2} \mathrm{O}+$ air $+\mathrm{MgSO}_{4}$ systems are simplified to $\mathrm{H}_{2} \mathrm{O}+\mathrm{N}_{2}+\mathrm{O}_{2}+\mathrm{Na}_{2} \mathrm{SO}_{4}$ and $\mathrm{H}_{2} \mathrm{O}+\mathrm{N}_{2}+\mathrm{O}_{2}+\mathrm{MgSO}_{4}$.

Figures 14-15 and S8 of Supporting Information show graphically the modeling results for some systems. Figure 14 shows the air solubilities in aqueous $\mathrm{NaCl}$ solution at $338.15 \mathrm{~K}$. The gas solubility difference between different pressures decrease with increasing salt molality.

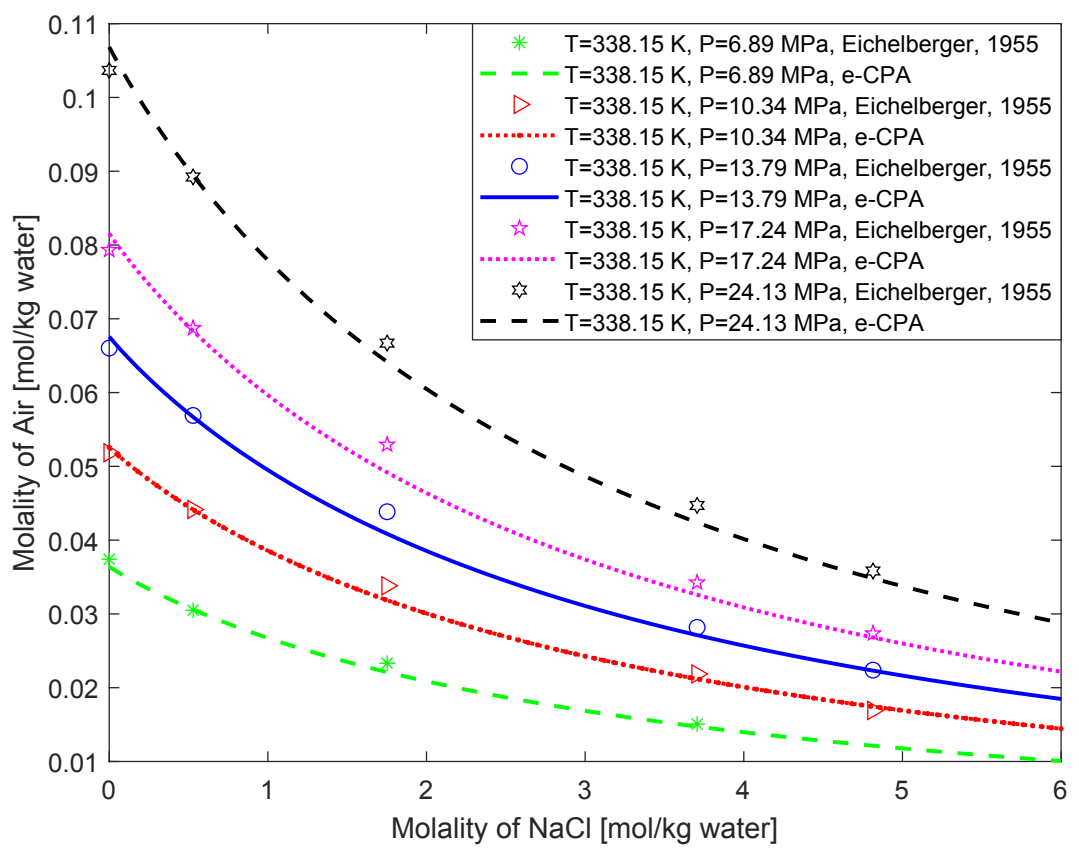

Figure 14. Solubilities of air in aqueous $\mathrm{NaCl}$ solutions ${ }^{55}$ at $338.15 \mathrm{~K}$.

Figure S8 of Supporting Information shows the air (as well as $\mathrm{N}_{2}$ and $\mathrm{O}_{2}$ ) solubilities in the aqueous $\mathrm{NaCl}$ solution. From the modeling results, it can be seen that $\mathrm{N}_{2}$ contributes about $2 / 3$ to the air solubilities, and $\mathrm{O}_{2}$ contributes about $1 / 3$ to the air solubilities. 


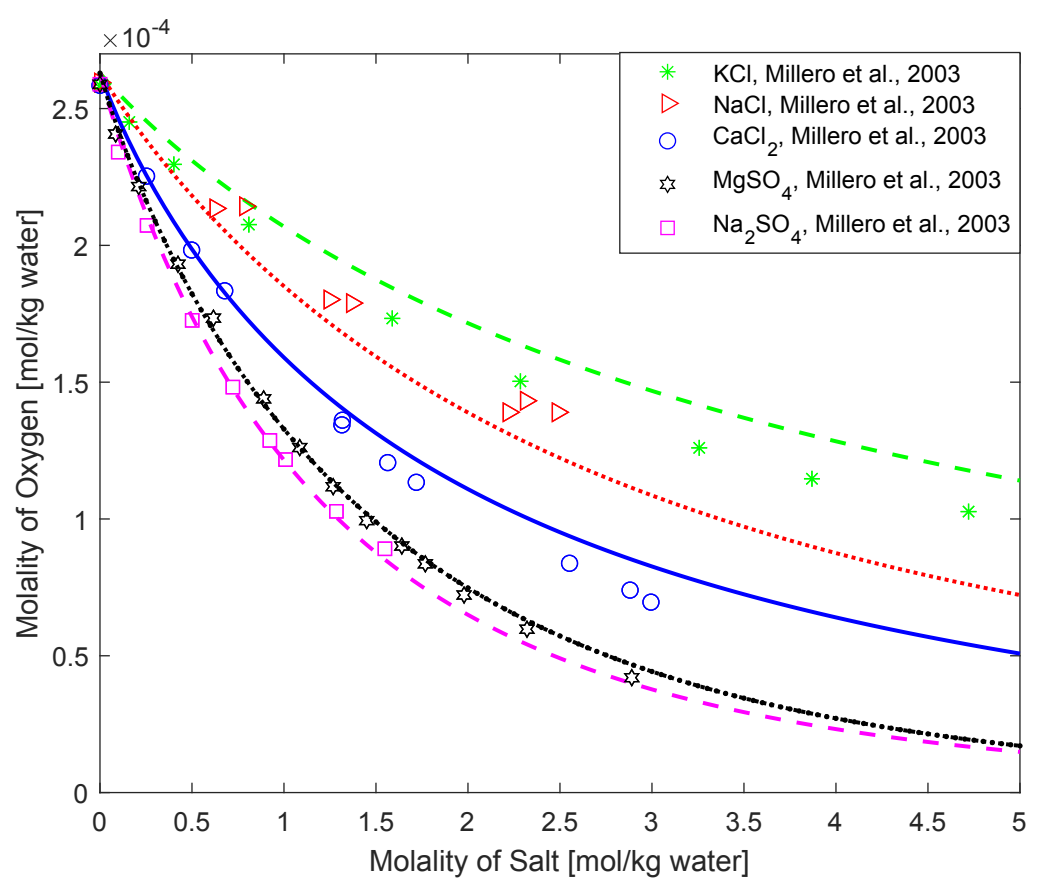

Figure 15. Solubilities of $\mathrm{O}_{2}$ (in air) in aqueous solutions of different salts at $298.15 \mathrm{~K}$ and atmospheric pressure.

Figure 15 shows the air solubilities in different aqueous electrolyte solutions at 298.15 $\mathrm{K}$ and atmospheric pressure. It can be seen from Figure 15 that the salting-out effects on air in water at $298.15 \mathrm{~K}$ follow the sequence of $\mathrm{KCl}<\mathrm{NaCl}<\mathrm{CaCl}_{2}<\mathrm{MgSO}_{4}<\mathrm{Na}_{2} \mathrm{SO}_{4}$ with the same molality. This order corresponds to the ion hydration abilities, and it is the same as the salting-out effects on $\mathrm{N}_{2}$ (Figure 3), if $\mathrm{KCl}$ is ignored.

\subsection{Predictions of Solubilities of Gas Mixtures in Aqueous Multi-Salt Solutions}

Earth and industrial fluids always contain more than one salt, so extension of thermodynamic models to multi-salt systems is important. In this work, there are no interaction parameter between different salts (ions) considered, i.e. no new adjustable parameters are introduced. That means the modeling results of multi-salt systems are straight predictions.

Prior to modeling the gas solubilities in aqueous multi-salt solutions, the model is validated for aqueous multi-salt solutions. Table 6 shows the modelling performance 
for osmotic coefficients and gas solubilities of aqueous multi-salt solutions. Figure 16 shows graphically the air solubilities in multi-salt systems.

Table 6. Predictive performance of e-CPA for osmotic coefficients $\Phi$ (at 298.15 K) and $\mathrm{O}_{2}$ (in air) solubilities in aqueous multi-salt solutions at $298.15 \mathrm{~K}$.

\begin{tabular}{|c|c|c|c|c|c|c|c|c|c|}
\hline \multirow{3}{*}{ Salts } & \multicolumn{3}{|c|}{$\Phi$} & \multicolumn{6}{|c|}{$\mathrm{O}_{2}$ solubilities } \\
\hline & \multirow{2}{*}{$\mathrm{I}^{\mathrm{a}}$} & \multirow{2}{*}{$\mathrm{Np}$} & \multicolumn{2}{|l|}{ RAD } & \multirow{2}{*}{$\mathrm{T}[\mathrm{K}]$} & \multirow{2}{*}{$\begin{array}{l}\mathrm{P} \\
{[\mathrm{MPa}]}\end{array}$} & \multirow{2}{*}{ Gas mixture } & \multirow[t]{2}{*}{$\mathrm{Np}$} & \multirow[t]{2}{*}{$\operatorname{RAD}[\%]$} \\
\hline & & & {$[\%]$} & $1^{\mathrm{c}}$ & & & & & \\
\hline \multirow[t]{2}{*}{$\mathrm{Na}_{2} \mathrm{SO}_{4}+\mathrm{MgSO}_{4}{ }^{\mathrm{b}}$} & $0.8-12.0$ & $49^{80}$ & 7.9 & $0.0-$ & 298.15 & 0.101 & $\operatorname{Air}\left(\mathrm{N}_{2}+\mathrm{O}_{2}\right)$ & \multirow{2}{*}{$8^{58}$} & \multirow{2}{*}{$3.8^{\mathrm{d}}$} \\
\hline & & & & 10.5 & & & & & \\
\hline \multirow[t]{2}{*}{$\mathrm{NaCl}+\mathrm{Na}_{2} \mathrm{SO}_{4}{ }^{\mathrm{b}}$} & $0.5-10.8$ & $157^{80}$ & 2.1 & $0.0-$ & 298.15 & 0.101 & $\operatorname{Air}\left(\mathrm{N}_{2}+\mathrm{O}_{2}\right)$ & \multirow{2}{*}{$10^{58}$} & \multirow{2}{*}{$6.9^{c}$} \\
\hline & & & & 6.0 & & & & & \\
\hline $\mathrm{NaCl}+\mathrm{KCl}+\mathrm{CaCl}_{2}$ & 14.0 & $2^{52}$ & 2.7 & 1.0 & 308.15 & 8.000 & $\mathrm{~N}_{2}+\mathrm{CO}_{2}$ & $7^{52}$ & $5.1^{\mathrm{e}} / 6.4^{\mathrm{f}}$ \\
\hline
\end{tabular}

a. ionic strength [mol/ $\mathrm{kg}$ water]; b. In the experimental data of $\mathrm{Na}_{2} \mathrm{SO}_{4}+\mathrm{MgSO}_{4}$ and $\mathrm{NaCl}+\mathrm{Na}_{2} \mathrm{SO}_{4}$ systems, the molality of each salt is very similar with each other. In the calculations for these systems, we assume that each salt has the same molality; c. salt molality: $\mathrm{Na}_{2} \mathrm{SO}_{4}+\mathrm{MgSO}_{4}\left(\mathrm{Na}_{2} \mathrm{SO}_{4}: 0-1.5, \mathrm{MgSO}_{4}: 0-1.5\right), \mathrm{NaCl}+\mathrm{Na}_{2} \mathrm{SO}_{4}(\mathrm{NaCl}: 0-$ 1.49, $\left.\mathrm{Na}_{2} \mathrm{SO}_{4}: 0-1.49\right), \mathrm{NaCl}+\mathrm{KCl}+\mathrm{CaCl}_{2}\left(\mathrm{NaCl}: 0.30, \mathrm{KCl}: 0.24, \mathrm{CaCl}_{2}: 0.16\right)$; d the experimental studies are made for $\mathrm{H}_{2} \mathrm{O}+$ Air, but only solubilities of $\mathrm{O}_{2}$ is given; e. solubilities of $\mathrm{N}_{2}$; f. solubilities of $\mathrm{CO}_{2}$.

It should be noted that, there are no cation/anion-argon interaction parameters for $\mathrm{Na}_{2} \mathrm{SO}_{4}$ as discussed above, so it is assumed that there is no argon in the $\mathrm{H}_{2} \mathrm{O}+$ air $+\mathrm{Na}_{2} \mathrm{SO}_{4}+\mathrm{MgSO}_{4}$ and $\mathrm{H}_{2} \mathrm{O}+$ air $+\mathrm{NaCl}+\mathrm{Na}_{2} \mathrm{SO}_{4}$ systems. From the results in Table 6 and Figure 16, it can be seen that e-CPA has a good performance for the solubilities of gas mixtures in aqueous multi-salt solutions. 


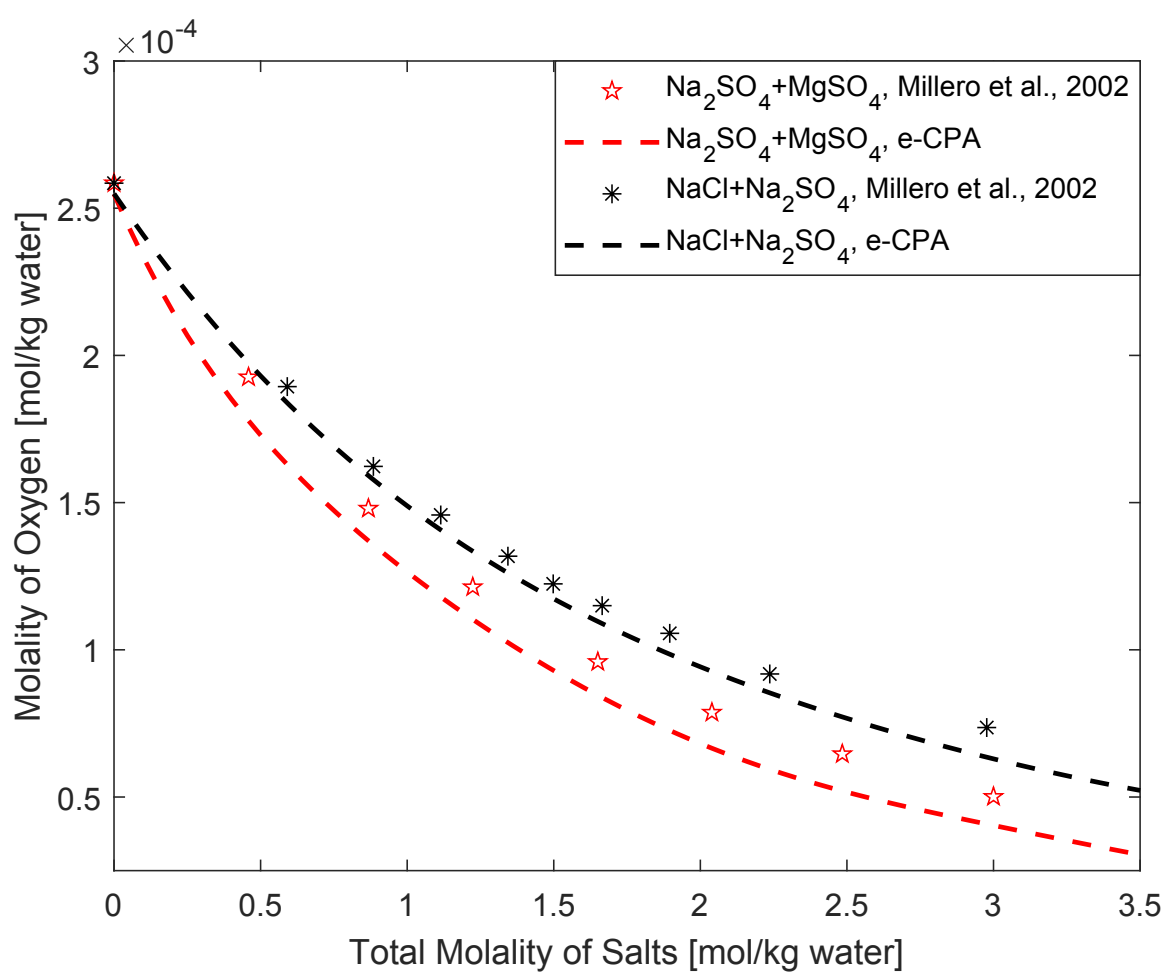

Figure 16. Solubilities of $\mathrm{O}_{2}$ (in air) in aqueous multi-salt solutions at $298.15 \mathrm{~K}$ and atmospheric pressure.

\section{Conclusions}

The solubilities of $\mathrm{N}_{2}, \mathrm{O}_{2}$ and argon in pure water and several aqueous electrolyte solutions have been systematically studied in this work with the e-CPA EoS. $\mathrm{O}_{2}$ and argon have similar solubilities in pure water, and the solubilities of $\mathrm{O}_{2}$ are about twice those of $\mathrm{N}_{2}$. The existence of a minimum is a common phenomenon for gas dissolution in pure water and aqueous electrolyte solutions. Different salts show different saltingout effects on gases in water, partly because of different ion hydration abilities. The existence of ion-association may cause unexpected salting-out effects. From the modeling results, it can be concluded that e-CPA provides good agreement with the experimental solubility data. The modeling studies include also gas mixtures and multisalt systems. In these cases and without additional adjustable parameters, e-CPA can also accurately predict the gas solubilities for these complex systems (gas mixtures and multi-salt solutions). Moreover, e-CPA shows a good performance on the salting-out effects. 
It can be overall concluded that e-CPA is an accurate and easy-to-use model, which can be adapted for new systems. For further studies, more experimental data over wider temperature-pressure-molality ranges would be useful.

\title{
Supporting Information
}

Supporting Information consists of three parts: The e-CPA EoS (Section A); Verification work for $\mathrm{H}_{2} \mathrm{O}+$ salt systems (Section B); CPA parameters of water and gases (Section C); Modeling results of gas solubility (Section D). This information is available free of charge via the Internet at http://pubs.acs.org/.

\section{Acknowledgment}

The authors are grateful to the European Research Council (ERC) for funding of this research under the European Union's Horizon 2020 research and innovation program (grant agreement No. 832460), ERC Advanced Grant project "New Paradigm in Electrolyte Thermodynamics".

\author{
Author Information \\ Corresponding author: \\ *E-mail address: xlia@kt.dtu.dk. Tel.: 0045-45252877. \\ *E-mail address: gk@kt.dtu.dk. Tel.: 0045-45252859.
}




\section{Reference}

(1) Ming, G.; Zhenhao, D. Prediction of oxygen solubility in pure water and brines up to high temperatures and pressures. Geochim. Cosmochim. Acta 2010, 74(19), 5631-5640.

(2) Zheng, J.; Mao, S. A thermodynamic model for the solubility of $\mathrm{N}_{2}, \mathrm{O}_{2}$ and $\mathrm{Ar}$ in pure water and aqueous electrolyte solutions and its applications. Appl. Geochem. 2019, 107, 58-79.

(3) Qin, J.; Rosenbauer, R. J.; Duan, Z. Experimental measurements of vapor-liquid equilibria of the $\mathrm{H}_{2} \mathrm{O}+\mathrm{CO}_{2}+\mathrm{CH}_{4}$ ternary system. J. Chem. Eng. Data 2008, 53(6), 1246-1249.

(4) Duan, Z.; Sun, R. An improved model calculating $\mathrm{CO}_{2}$ solubility in pure water and aqueous $\mathrm{NaCl}$ solutions from 273 to $533 \mathrm{~K}$ and from 0 to 2000 bar. Chem. Geol. 2003, 193(3-4), 257-271.

(5) O'Sullivan, T. D.; Smith, N. O. Solubility and partial molar volume of nitrogen and methane in water and in aqueous sodium chloride from 50 to 125. deg. and 100 to $600 \mathrm{~atm}$. J. Phys. Chem. 1970, 74(7), 1460-1466.

(6) Weathersby, P.; Homer, L. Solubility of inert gases in biological fluids and tissues: a review. Undersea biomedical research 1980, 7(4), 277-296.

(7) Smith, N. O.; Kelemen, S.; Nagy, B. Solubility of natural gases in aqueous salt solutions-II: Nitrogen in aqueous $\mathrm{NaCl}, \mathrm{CaCl}_{2}, \mathrm{Na}_{2} \mathrm{SO}_{4}$ and $\mathrm{MgSO}_{4}$ at room temperatures and at pressures below 1000 psia. Geochim. Cosmochim. Acta 1962, 26(9), 921-926.

(8) Clever, H. L.; Holland, C. J. Solubility of argon gas in aqueous alkali halide solutions. Temperature coefficient of the salting out parameter. J. Chem. Eng. Data 1968, 13(3), 411-414.

(9) Lang, W.; Zander, R. Salting-out of oxygen from aqueous electrolyte solutions: prediction and measurement. Ind. Eng. Chem. Fundam. 1986, 25(4), 775-782.

(10) Harvey, A. H.; Prausnitz, J. M. Thermodynamics of high-pressure aqueous systems containing gases and salts. AlChE J. 1989, 35(4), 635-644.

(11) Aasberg-Petersen, K.; Stenby, E.; Fredenslund, A. Prediction of high-pressure gas solubilities in aqueous mixtures of electrolytes. Ind. Eng. Chem. Res. 1991, 30(9), 2180-2185.

(12) Zuo, Y. X.; Guo, T. M. Extension of the Patel-Teja equation of state to the prediction of the solubility of natural gas in formation water. Chem. Eng. Sci. 1991, 46(12), 3251-3258.

(13) Søreide, I.; Whitson, C. H. Peng-Robinson predictions for hydrocarbons, $\mathrm{CO}_{2}, \mathrm{~N}_{2}$, and $\mathrm{H} 2 \mathrm{~S}$ with pure water and $\mathrm{NaCl}$ brine. Fluid Phase Equilib. 1992, 77, 217-240.

(14) Sun, R.; Dubessy, J. Prediction of vapor-liquid equilibrium and PVTx properties of geological fluid system with SAFT-LJ EOS including multi-polar contribution. Part II: Application to $\mathrm{H}_{2} \mathrm{O}-\mathrm{NaCl}$ and $\mathrm{CO}_{2}-\mathrm{H}_{2} \mathrm{O}-\mathrm{NaCl}$ System. Geochim. Cosmochim. Acta 2012, 88, 130-145.

(15) Ji, X.; Tan, S. P.; Adidharma, H.; Radosz, M. SAFT1-RPM approximation extended to phase equilibria and densities of $\mathrm{CO}_{2}-\mathrm{H}_{2} \mathrm{O}$ and $\mathrm{CO}_{2}-\mathrm{H}_{2} \mathrm{O}-\mathrm{NaCl}$ systems. Ind. Eng. Chem. Res. 2005, 44(22), 8419-8427.

(16) Haghighi, H.; Chapoy, A.; Tohidi, B. Methane and water phase equilibria in the presence of single and mixed electrolyte solutions using the cubic-plus-association equation of state. Oil \& Gas Science and Technology-Revue de l'IFP 2009, 64(2), 141-154.

(17) Tan, S. P.; Yao, Y.; Piri, M. Modeling the solubility of $\mathrm{SO}_{2}+\mathrm{CO}_{2}$ mixtures in brine at elevated pressures and temperatures. Ind. Eng. Chem. Res. 2013, 52(31), 10864-10872.

(18) Courtial, X.; Ferrando, N.; de Hemptinne, J.-C.; Mougin, P. Electrolyte CPA equation of state for very high temperature and pressure reservoir and basin applications. Geochim. Cosmochim. Acta 2014, 142, 1-14. 
(19) Rozmus, J.; de Hemptinne, J.-C.; Galindo, A.; Dufal, S.; Mougin, P. Modeling of strong electrolytes with ePPC-SAFT up to high temperatures. Ind. Eng. Chem. Res. 2013, 52(29), 9979-9994.

(20) Schreckenberg, J. M.; Dufal, S.; Haslam, A. J.; Adjiman, C. S.; Jackson, G.; Galindo, A. Modelling of the thermodynamic and solvation properties of electrolyte solutions with the statistical associating fluid theory for potentials of variable range. Mol. Phys. 2014, 112(17), 2339-2364.

(21) Gao, J.; Zheng, D. Q.; Guo, T. M. Solubilities of methane, nitrogen, carbon dioxide, and a natural gas mixture in aqueous sodium bicarbonate solutions under high pressure and elevated temperature. Journal of Chemical \& Engineering Data 1997, 42(1), 69-73.

(22) Sun, R.; Dubessy, J. Prediction of vapor-liquid equilibrium and PVTx properties of geological fluid system with SAFT-LJ EOS including multi-polar contribution. Part I: Application to $\mathrm{H}_{2} \mathrm{O}-\mathrm{CO}_{2}$ system. Geochimica et Cosmochimica Acta 2010, 74(7), 1982-1998.

(23) Sun, L.; Kontogeorgis, G. M.; von Solms, N.; Liang, X. Modeling of Gas Solubility Using the Electrolyte Cubic Plus Association Equation of State. Ind. Eng. Chem. Res. 2019, 58(37), 17555-17567. (24) Maribo-Mogensen, B.; Thomsen, K.; Kontogeorgis, G. M. An electrolyte CPA equation of state for mixed solvent electrolytes. AlChE J. 2015, 61(9), 2933-2950.

(25) Kontogeorgis, G. M.; Voutsas, E. C.; Yakoumis, I. V.; Tassios, D. P. An equation of state for associating fluids. Ind. Eng. Chem. Res. 1996, 35(11), 4310-4318.

(26) Soave, G. Equilibrium constants from a modified Redlich-Kwong equation of state. Chem. Eng. Sci. 1972, 27(6), 1197-1203.

(27) Debye, P.; Huckel, E. Zur Theorie der Elektrolyte. I. Gefrierpunktserniedrigung und verwandte Erscheinungen. Physikalische Zeitschrift 1923, 24, 185-206.

(28) Born, M. Volumen und hydratationswärme der ionen. Zeitschrift für Physik A Hadrons and Nuclei 1920, $1(1), 45-48$.

(29) Michelsen, M. L.; Mollerup, J. Thermodynamic modelling: fundamentals and computational aspects. Tie-Line Publications: 2004.

(30) Liang, X. Numerical aspects of phase equilibrium calculations with the cubic and association models. Ind. Eng. Chem. Res. 2018, 57(42), 14273-14285.

(31) Sun, L.; Liang, X.; von Solms, N.; Kontogeorgis, G. M. Thermodynamic modeling of gas solubility in aqueous solutions of quaternary ammonium salts with the e-CPA equation of state. Fluid Phase Equilib. 2020, 507, 112423.

(32) Borina, A.; Samojlov, O. Y. On connection of temperature dependence of neon solubility in aqueous solutions with structural solvent state. Zhurnal Strukturnoj Khimii 1974, 15(3), 395-402.

(33) Frank, H. S.; Quist, A. S. Pauling's model and the thermodynamic properties of water. J. Chem. Phys. 1961, 34(2), 604-611.

(34) I.V.Pobelov. Chemistry, Molecular Sciences and Chemical Engineering: Thermodynamics of ionic processes in solutions. University of Bern: Bern, Switzerland, 2018.

(35) Jhon, M.; Eyring, H.; Sung, Y. Solubility of gases in water. Chem. Phys. Lett. 1972, 13(1), 36-39.

(36) Battino, R.; Seybold, P. G. The $\mathrm{O}_{2} / \mathrm{N}_{2}$ ratio gas solubility mystery. J. Chem. Eng. Data 2011, 56(12), 5036-5044.

(37) Abraham, M. H.; Andonian-Haftvan, J.; Whiting, G. S.; Leo, A.; Taft, R. S. Hydrogen bonding. Part 34. The factors that influence the solubility of gases and vapours in water at $298 \mathrm{~K}$, and a new method for its determination. J. Chem. Soc., Perkin Trans. 2 1994, (8), 1777-1791.

(38) Lum, K.; Chandler, D.; Weeks, J. D. Hydrophobicity at small and large length scales. Journal of Physical Chemistry B 1999, 103(22), 4570-4577. 
(39) Bakulin, A. A.; Pshenichnikov, M. S.; Bakker, H. J.; Petersen, C. Hydrophobic molecules slow down the hydrogen-bond dynamics of water. J. Phys. Chem. A 2011, 115(10), 1821-1829.

(40) Kuenen, J. P. LVIII. Mixtures of hydrochloric acid and methylether. The London, Edinburgh, and Dublin Philosophical Magazine and Journal of Science 1901, 1(5), 593-598.

(41) Uribe, F. A.; Bard, A. J. Electrochemistry in liquid ammonia. 5. Electroreduction of oxygen. Inorg. Chem. 1982, $21(8), 3160-3163$.

(42) Horiuti, J. On the solubility of gas and coefficient of dilatation by absorption. Sci. Papers Inst. Phys. Chem. Res.(Japan) 1931, 17, 125-256.

(43) Tammann, G. Die Gaslöslichkeit in Abhängigkeit von der Temperatur. Zeitschrift für anorganische und allgemeine Chemie 1926, 158(1), 17-24.

(44) Groisman, A. S.; Khomutov, N. Solubility of oxygen in electrolyte solutions. Russ. Chem. Rev. 1990, 59(8), 707.

(45) Pray, H. A.; Schweickert, C.; Minnich, B. H. Solubility of hydrogen, oxygen, nitrogen, and helium in water at elevated temperatures. Ind. Eng. Chem. 1952, 44(5), 1146-1151.

(46) Brodén, A.; Simonson, R. Solubility of oxygen. 1. Solubility of oxygen in water at temperatures less than or equal to 150 degrees Celsius and pressures less than or equal to 5 oxygen partial pressures. Svensk papperstidning, Nordisk cellulosa 1978, 81(17), 541-544.

(47) Cramer, S. D. Oxygen solubility in brines. Ind. Eng. Chem. 1984, 23(3), 618-620.

(48) Schroder, W. A. The Preservation of Historical Areas. Ky. LJ 1973, 62, 940.

(49) Winkler, L. Gesetzmässigkeit bei der Absorption der Gase in Flüssigkeiten. Zeitschrift für Physikalische Chemie 1892, 9(1), 171-175.

(50) Wheast, R. C. Handbook of chemistry and physics. CRC press: New York, 1983.

(51) Dhima, A.; de Hemptinne, J.-C.; Jose, J. Solubility of hydrocarbons and $\mathrm{CO}_{2}$ mixtures in water under high pressure. Ind. Eng. Chem. Res. 1999, 38(8), 3144-3161.

(52) Liu, Y.; Hou, M.; Ning, H.; Yang, D.; Yang, G.; Han, B. Phase equilibria of $\mathrm{CO}_{2}+\mathrm{N}_{2}+\mathrm{H}_{2} \mathrm{O}$ and $\mathrm{N}_{2}+\mathrm{CO}_{2}+\mathrm{H}_{2} \mathrm{O}+\mathrm{NaCl}+\mathrm{KCl}+\mathrm{CaCl}_{2}$ systems at different temperatures and pressures. J. Chem. Eng. Data 2012, 57(7), 1928-1932.

(53) Ohgaki, K.; Takano, K.; Sangawa, H.; Matsubara, T.; Nakano, S. Methane Exploitation by Carbon Dioxide from Gas Hydrates_-Phase Equilibria for $\mathrm{CO}_{2}-\mathrm{CH}_{4}$ Mixed Hydrate System. J. Chem. Eng. Jpn. 1996, 29(3), 478-483.

(54) Mckee, O. G. A Study of Solubilities of Several Gases in Water. Purdue University: West Lafayette, 1953.

(55) Eichelberger, W. C. Solubility of Air in Brine at High Pressures. Ind. Eng. Chem. 1955, 47(10), 2223-2228.

(56) Battino, R.; Rettich, T. R.; Tominaga, T. The solubility of nitrogen and air in liquids. J. Phys. Chem. Ref. Data 1984, 13(2), 563-600.

(57) Millero, F. J.; Huang, F.; Laferiere, A. L. Solubility of oxygen in the major sea salts as a function of concentration and temperature. Mar. Chem. 2002, 78(4), 217-230.

(58) Millero, F. J.; Huang, F.; Laferiere, A. L. The solubility of oxygen in the major sea salts and their mixtures at 25 C. Geochim. Cosmochim. Acta 2002, 66(13), 2349-2359.

(59) Novotny, P.; Sohnel, O. Densities of binary aqueous solutions of 306 inorganic substances. J. Chem. Eng. Data 1988, 33(1), 49-55.

(60) Bikov, M. The solubility of gases in solutions of salts under pressure at high temperature. $T r$. Voronezhsk. Gos. Univ. 1937, 9(29), 51. 
(61) Braun, L. Über die Absorption von Stickstoff und von Wasserstoff in wässerigen Lösungen verschieden dissociierter Stoffe. Zeitschrift für Physikalische Chemie 1900, 33(1), 721-739.

(62) Yasunishi, A. Solubilities of sparingly soluble gases in aqueous sodium sulfate and sulfite solutions. J. Chem. Eng. Jpn. 1977, 10(2), 89-94.

(63) Iwai, Y.; Eya, H.; Itoh, Y.; Aral, Y.; Takeuchi, K. Measurement and correlation of solubilities of oxygen in aqueous solutions containing salts and sucrose. Fluid Phase Equilib. 1993, 83, 271-278.

(64) Elliot, A. J.; Chenier, M. P.; Ouellette, D. C. Solubilities of hydrogen and oxygen in concentrated lithium salt solutions. Fusion Eng. Des. 1990, 13(1), 29-31.

(65) Janata, E.; Kelm, M.; Ershov, B. Solubility of oxygen and nitrous oxide in aqueous solutions of $\mathrm{NaCl}$ : a pulse radiolysis study. Radiat. Phys. Chem. 2002, 63(2), 157-160.

(66) Hutten, H.; Meiners, K.; Zander, R. Ein polarographisches Verfahren zur Bestimmung von Sauerstoff-Löslichkeitskoeffizienten in wäßrigen Elektrolytlösungen-A method for the polarographic measurement of oxygen solubility coefficients in hydrous solutions of electrolytes. Biomed. Eng. 1982, 27(1-2), 7-13.

(67) Eucken, A.; Hertzberg, G. Aussalzeffekt und ionenhydratation. Zeitschrift für Physikalische Chemie 1950, 195(1), 1-23.

(68) Armenante, P. M.; Karlsson, H. T. Salting-out parameters for organic acids. J. Chem. Eng. Data 1982, 27(2), 155-156.

(69) Geffcken, G. Beiträge zur kenntnis der löslichkeitsbeeinflussung. Zeitschrift für Physikalische Chemie 1904, 49(1), 257-302.

(70) Yasunishi, A. Solubility of oxygen in aqueous electrolyte solutions. Kagaku Kogaku Rombunshu 1978, 4(2), 185-189.

(71) Åkerlöf, G. The solubility of noble gases in aqueous salt solutions at $25^{\circ} . \mathrm{J}$. Am. Chem. Soc. 1935 , 57(7), 1196-1201.

(72) Abrosimov, V.; Badelin, V.; Krestov, G. Dependence of argon solubility in aqueous solutions of alkali metal halides on electrolyte concentration and temperature. Izvestiya Vysshikh Uchebnykh Zavedenij, Khimiya i Khimicheskaya Tekhnologiya 1976, 19(9), 1381-1386.

(73) Ben-Naim, A.; Egel-Thal, M. Thermodynamics of aqueous solutions of noble gases. III. Effect of electrolytes. J. Phys. Chem. 1965, 69(10), 3250-3253.

(74) Degrève, L.; Mazzé, F. M. Molecular simulation of LiCl aqueous solutions. Mol. Phys. 2003, 101(10), 1443-1453.

(75) Millero, F. J.; Huang, F.; Graham, T. B. Solubility of oxygen in some 1-1, 2-1, 1-2, and 2-2 electrolytes as a function of concentration at 25 C. J. Solution Chem. 2003, 32(6), 473-487.

(76) MacArthur, C. Solubility of oxygen in salt solutions and the hydrates of these salts. J. Phys. Chem. 2002, 20(6), 495-502.

(77) Millero, F. J.; Huang, F. Solubility of oxygen in aqueous solutions of $\mathrm{KCl}, \mathrm{K}_{2} \mathrm{SO}_{4}$, and $\mathrm{CaCl}_{2}$ as a function of concentration and temperature. J. Chem. Eng. Data 2003, 48(4), 1050-1054.

(78) Miyamoto, H.; Yampolski, Y.; Young, C. L. IUPAC-NIST solubility data series. 103. Oxygen and ozone in water, aqueous solutions, and organic liquids (supplement to solubility data series volume 7).

J. Phys. Chem. Ref. Data 2014, 43(3), 033102.

(79) John, V. Introduction to engineering materials. Macmillan International Higher Education: London, 1992.

(80) Wood, J. R. Thermodynamics of brine-salt equilibria-I. The systems NaCl-KCl- $\mathrm{MgCl}_{2}-\mathrm{CaCl}_{2}-$ $\mathrm{H}_{2} \mathrm{O}$ and $\mathrm{NaCl}-\mathrm{MgSO}_{4}-\mathrm{H}_{2} \mathrm{O}$ at 25 C. Geochim. Cosmochim. Acta 1975, 39(8), 1147-1163. 


\section{For Table of Contents Only}

Caption:

Dissolution of Air in Aqueous Electrolyte Solutions

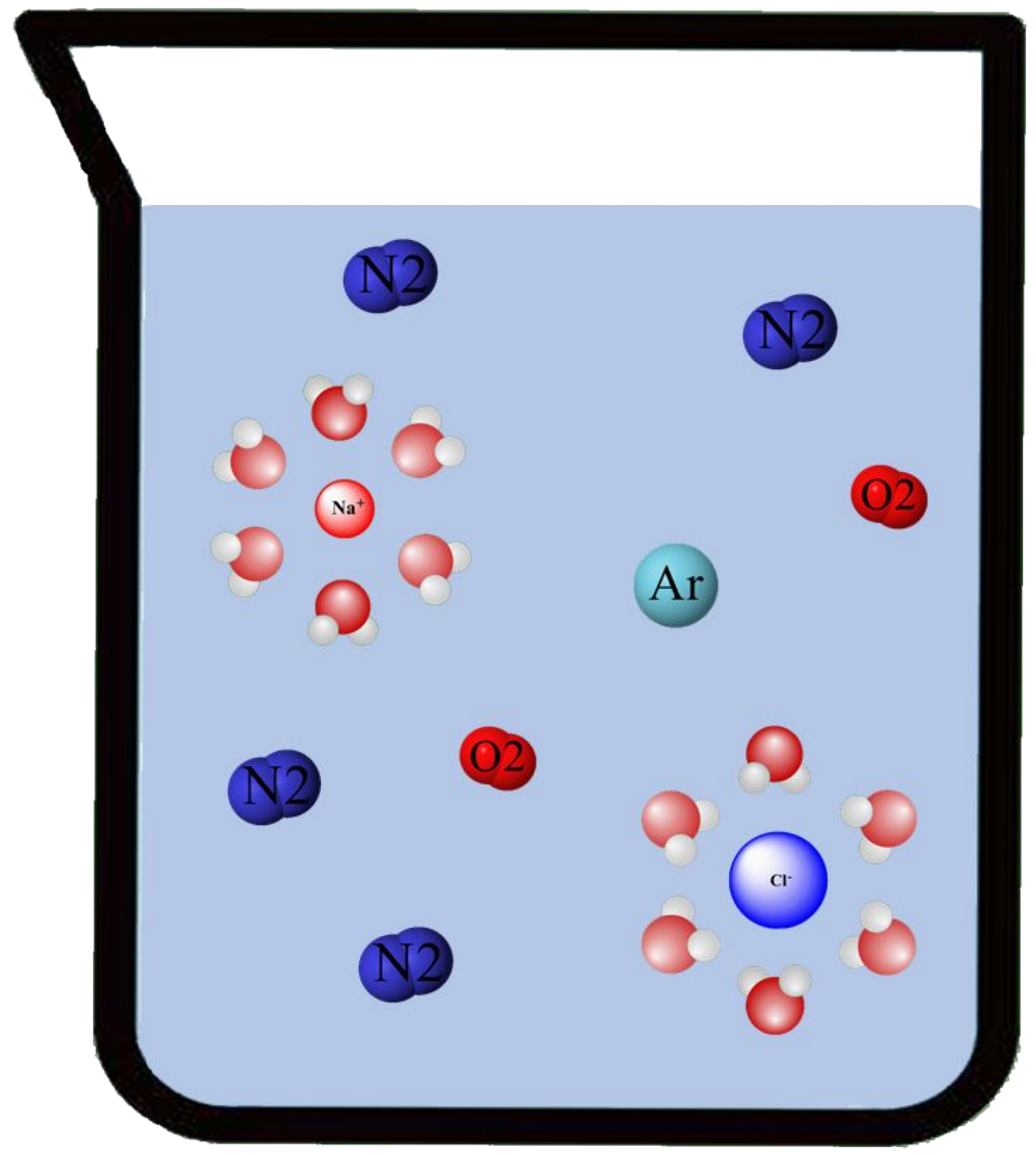




\section{Graphic}

\section{Dissolution of Air in Aqueous Electrolyte Solutions}

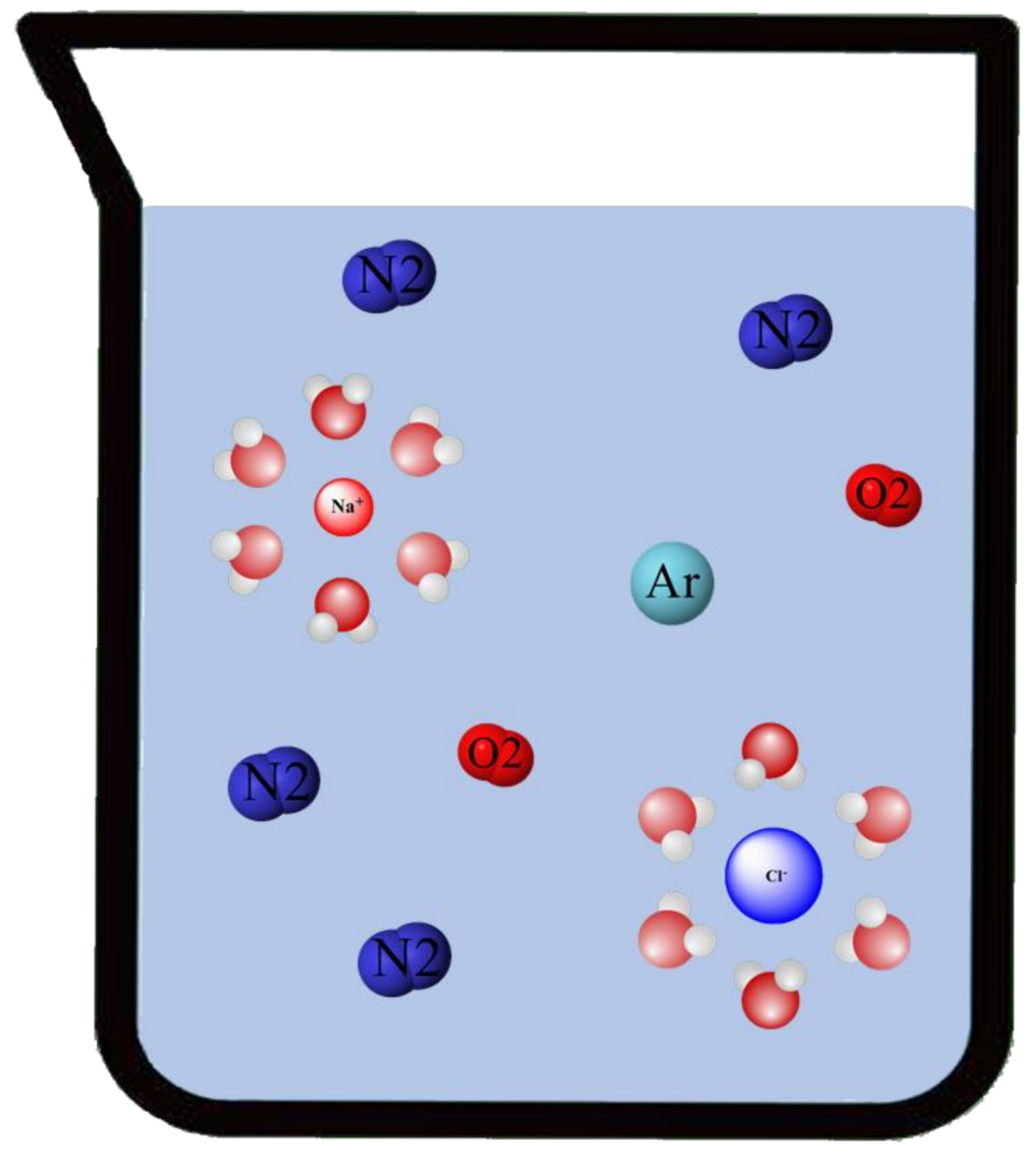

